\title{
Arte e geometria nel disegno tessile
}

\author{
Stefano Chiarenza
}

Abstract

Il presente articolo evidenzia le relazioni tra disegno tessile, arte e geometria sottolineando alcuni temi chiave, quali quelli di simmetria, struttura e forma, presenti sia nell'ornamentazione della superficie che nella costruzione del tessuto stesso. Molti concetti geometrici di grande utilità nel disegno tessile sono infatti relegati a una letteratura matematica di difficile interpretazione per coloro che si occupano di disegno del tessuto che agiscono spesso ancora sfruttando una consapevolezza intuitiva dell'ordine geometrico. Vengono pertanto brevemente riesaminati e discussi i principi e le regole sottese al disegno e alla struttura tessile, contestualizzandoli al fine non solo di veicolare un approccio scientifico alla progettazione grafica ma di stimolare una riflessione sulla didattica e sulla ricerca nella disciplina.

Parole chiave

simmetria, pattern, texture, modularità, ornamentazione.

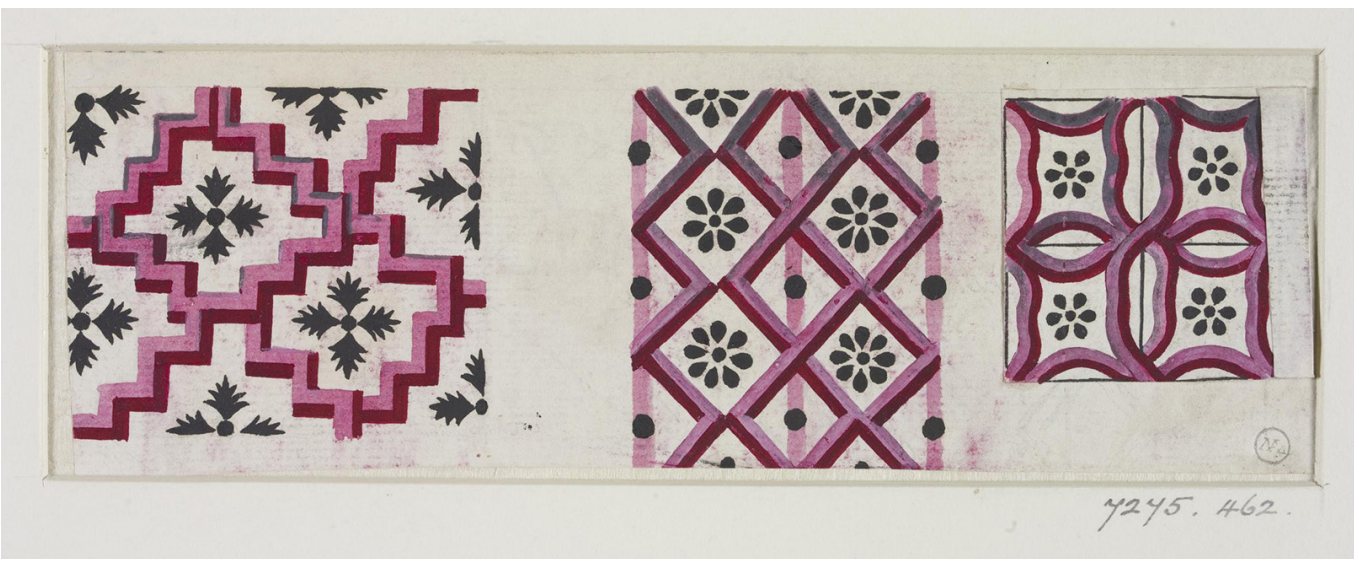




\section{Introduzione}

Il design tessile costituisce un ambito di particolare interesse per gli studiosi che si occupano di disegno e geometria. In esso infatti è possibile ritrovare una serie di tematiche concettuali quali quelle di pattern, struttura, forma e proporzione che, se da un lato costituiscono problemi basilari di alcune scienze, come ad esempio la matematica e la cristallografia, dall'altro appaiono strettamente relazionate alla progettazione grafica e alle arti decorative in genere. Il disegno e l'ornamento infatti hanno trovato da sempre ampia ispirazione proprio nelle forme equilibrate e complesse della natura. Dall'armoniosità delle manifestazioni macroscopiche alla bellezza di quelle microscopiche, derivata da un rigoroso ordine matematico, queste mostrano, a una attenta osservazione, lo stretto legame tra arte e scienza. L'attrazione naturale verso alcune forme è in realtà legata alla presenza di strutture regolari di base su cui si declinano, con infinite e imprevedibili variazioni, una serie di sovrastrutture configurative. Proprio tale caratteristica costituisce il concetto più evidente presente nel disegno tessile. Come nota Horne, infatti, "such a relationship between a basic formal structure and the individuality of stylistic approaches to its decoration forms a framework for the construction of regularly repeating designs" [Horne 2000, p. I].

Il problema della struttura e della regolarità nell'arte tessile può essere in realtà indagato da due punti di vista. Uno, oggetto della trattazione del primo paragrafo, riguarda la stampa della superficie. L'altro, esaminato nel paragrafo successivo, riguarda invece l'armatura del tessuto, owero il modo in cui vengono intrecciati i fili che ne costituiscono la sua composizione materiale. I due aspetti, evidentemente non privi di tratti comuni e certamente sovrapposti, mettono in luce le differenze tra pattern e texture, aggiungendosi a quest'ultima, oltre alla qualità percettiva del pattern, anche quella tattile.
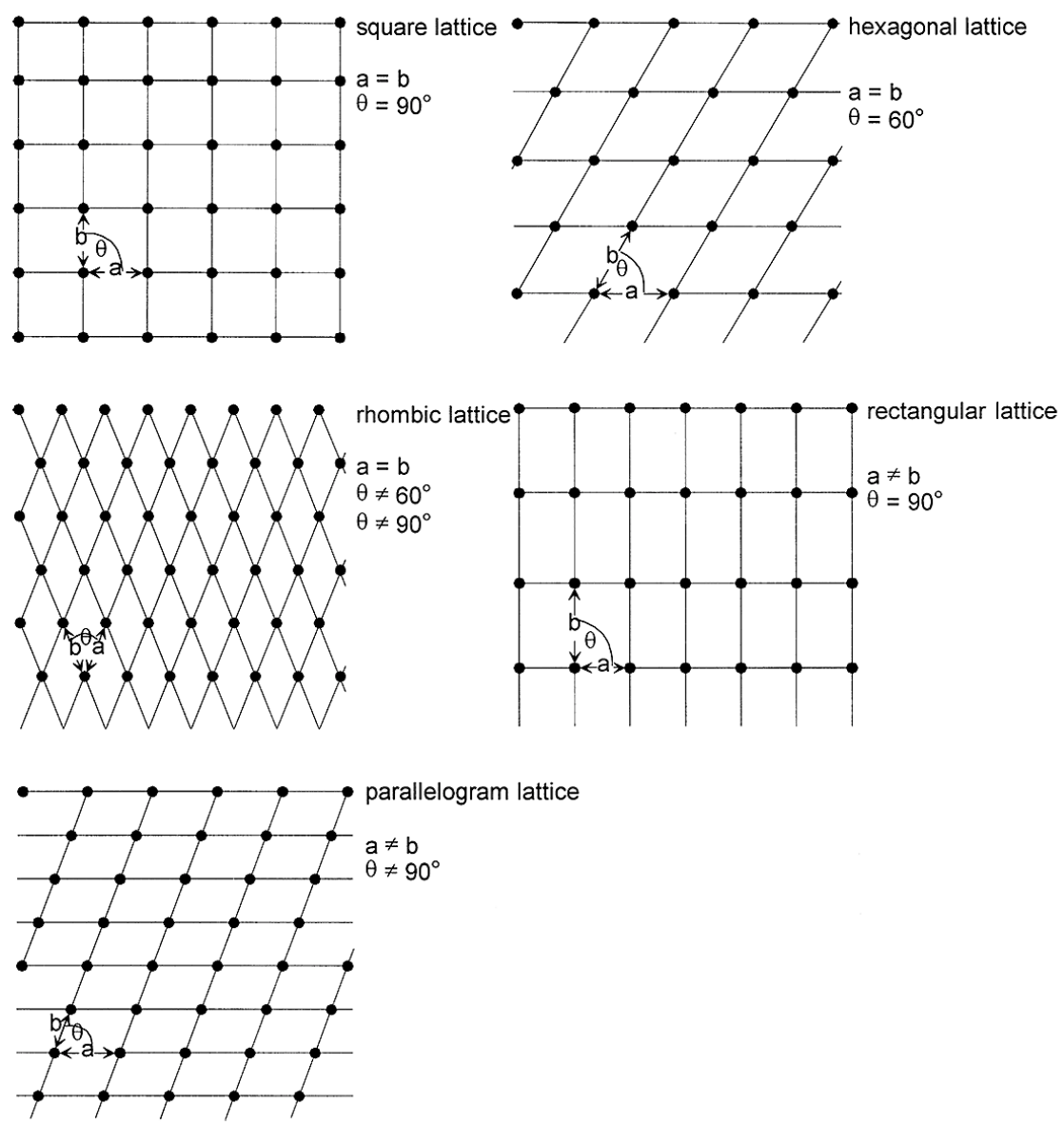


\section{Struttura, simmetria e invenzione nel decoro a stampa}

La decorazione di una superficie tessile si basa essenzialmente sulla definizione di un pattern i cui presupposti fondamentali sono quelli di struttura e simmetria. Relativamente alla struttura, già Meyer, in uno dei primi significativi manuali sull'ornamentazione [I], considera alla base della decorazione geometrica piana la presenza di una griglia di suddivisione sottesa al disegno, fondata su geometrie di varia natura, ma strutturata frequentemente su quadrato e triangolo equilatero. Tale griglia funge da regola per la ripetizione della composizione [Meyer 1920, pp. 3, 4].

Egli anticipa in realtà una serie di studi successivi che mettono in evidenza come, in tutti i disegni basati sulla ripetizione sia sempre riconoscibile un implicito reticolo di punti (griglia) che definisce le unità di base (o moduli) del pattern [Stephenson, Suddards 1897; Christie 1910, Day 1903]. Sebbene le composizioni possano essere di più tipi [2], la struttura assume un ruolo chiave nei cosiddetti motivi stampati a rapporto continuo meglio noti come all-over [3]. Questi sono caratterizzati da combinazioni modulari decorative che, seppure ricadenti all'interno di una cornice unitaria, non sono mai vincolate né dalla forma di quest'ultima, né all'interno di quella specifica area, contemplando progettualmente la possibilità di ripetizione, potenzialmente allinfinito. Ripetizione che avviene in tutte le direzioni del piano, ovvero in verticale, orizzontale o diagonale. In generale è possibile individuare, sul piano, solo cinque tipologie distinte di unità reticolari [Grünbaum, Shephard 1987, p. 262; Bravais 1949 , pp. 27, 28] che possono essere sfruttate per generare i diversi tipi di griglie: parallelogrammi, rettangoli, rombi, quadrati ed esagoni [4]. Si tratta, nello specifico, di reticoli di punti che determinano disposizione e movimento dei motivi di base caratterizzanti l'all-over.

Se la struttura rappresenta, dunque, uno degli aspetti fondamentali dellimpianto grafico di un pattern [Washburn, Crowe 199I] un ruolo chiave nella composizione è svolto anche dalla simmetria, intendendo tale principio in maniera estesa, ovvero inclusiva di tutte le trasformazioni isomorfe sul piano quali traslazione, rotazione, riflessione e glissosimmetria. Sicuramente, nella realizzazione di schemi bidimensionali a stampa su tessuto è facile ritrovare la sistematica esplorazione di diversi gruppi di simmetria e riscontrare come operazioni puramente matematiche vengono ricondotte ad attività artistica. Scrive Kappraff che "nowhere is this tension between artists and their art more evident than with regard to the issue of symmetry" [Kappraff 1990, p. 405].

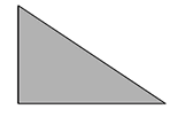

a)
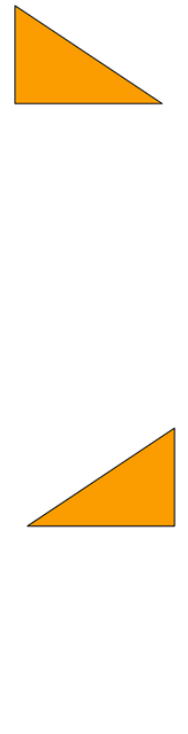

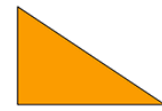

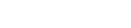

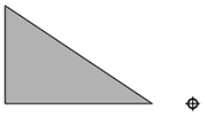

b)

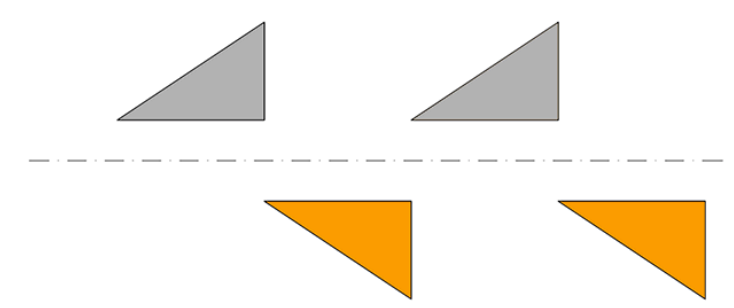

d) 
Fig. 3. A sinistra: progetto grafico per stampa tessile. (archivio delVictoria ca (archivio del Victori and Albert Museum: <http://collections.vam. ac.uk/item/O I0 I5840>) A destra: schema grafico con evidenziazione della glissosimmetria generativa.
I motivi [5] rappresentano i blocchi costitutivi di ogni pattern [Hann 2003]. Essi possono essere simmetrici o asimmetrici. Sono simmetrici quelli caratterizzati dalla presenza di due o più parti aventi stessa forma, grandezza e contenuto [6]. Sono asimmetrici quando costituiti da una singola unità che non può essere geometricamente suddivisa in due o più parti uguali. La traslazione rappresenta la più comune trasformazione alla base della ripetizione di un motivo. L'unione con una o più delle altre isometrie piane permette di generare complessivamente 17 classi di pattern. In particolare si distinguono: quattro classi ottenibili senza ricorrere alla rotazione e che sfruttano traslazione, riflessione, glissosimmetria o combinazioni di esse; cinque che sfruttano, oltre alle isometrie già citate, anche la rotazione $\left(180^{\circ}\right)$; tre, su griglia esclusivamente esagonale, che ricorrono invece anche alla rotazione (120 $)$; tre, basate su griglia quadrata, che sfruttano rotazioni di $90^{\circ}$; due, infine, su griglie esagonali, che unitamente a riflessioni e glissosimmetrie, vedono l'uso di rotazioni di $60^{\circ}$. Ognuna di esse si basa su una delle cinque strutture reticolari di Bravais. Le possibilità di combinazione consentono, dunque, la realizzazione di pattern estremamente vari sui quali incide nondimeno la scelta del motivo, in grado di influenzarne, spesso in maniera significativa, l'organizzazione percettiva. In altre parole, il motivo e la strutturazione dello stesso nel pattern possono mettere in luce alcune isometrie anziché altre. Come è infatti stato osservato in uno specifico studio "each type of wallpaper pattern is defined by its lattice type and a list of isometric transformations (i.e., transformations that preserve distance: translation, rotation, reflection, and glide reflection) that map the pattern onto itself. When different perceptual organizations are induced in wallpaper patterns by different motifs, different isometries become salient to the observer. As a result, formally isomorphic wallpaper patterns can appear to be of different types, and formally different wallpaper patterns may appear to be similar" [Kubovy 1994, p. 190].

Su tali presupposti è possibile riportare anche al disegno tessile quanto sottolineato da $\mathrm{Da}$ vis e Hersh a proposito delle implicite relazioni tra arte e matematica ovvero che "through intuition, the artist is often an unconscious mathematician, discovering, rediscovering, and exploring ideas of spatial arrangement, symmetry, periodicities, combinatorics and transformations and discovering, in a visual sense, theorems of geometry" [Davis e Hersh 1986, p. 43].
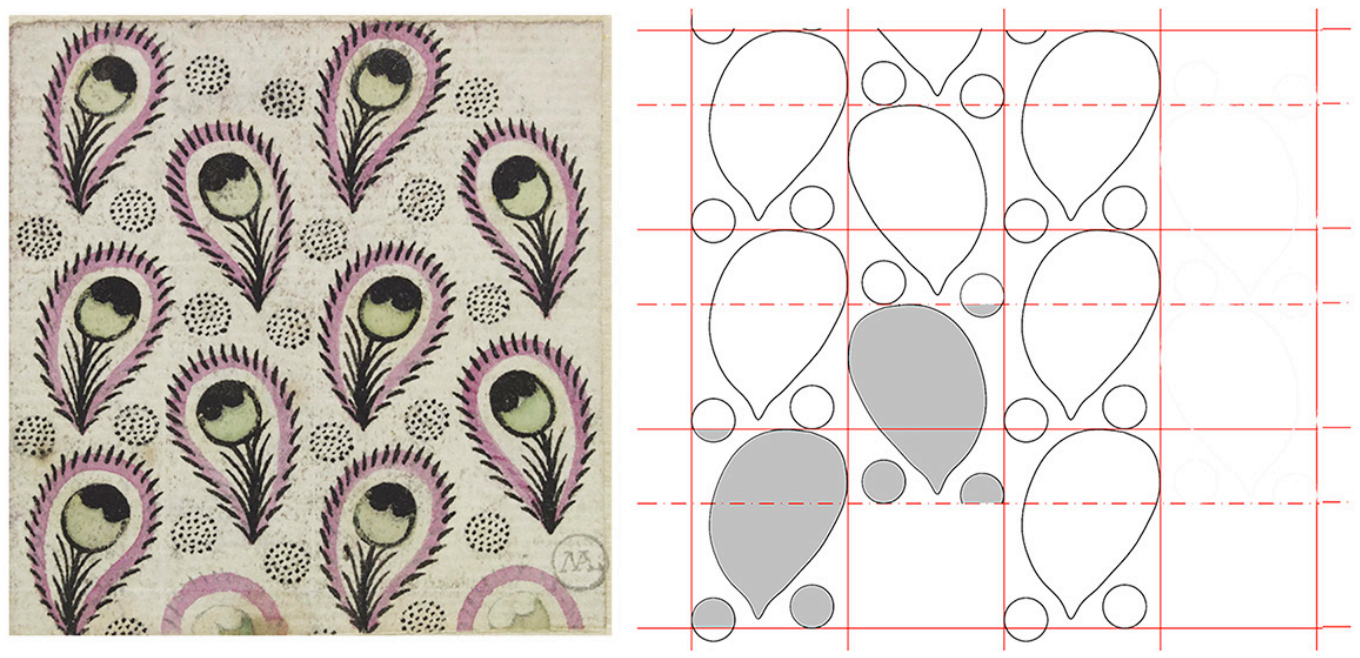

\section{La modularità nell'intreccio}

La struttura costitutiva del tessuto rappresenta un altro elemento di congiunzione tra design tessile, geometria e matematica. L'armatura di un tessuto, ovvero il modo in cui si intrecciano i fili di ordito e di trama, è ciò che caratterizza la texture e il disegno indipendentemente dalla stampa. Nella stragrande maggioranza dei tessuti, l'ordine in cui i fili sono intrecciati si ripete infatti periodicamente secondo le direzioni di trama (orizzontale) e ordito (verticale). La più piccola, singola parte ricorrente è nota come ripetizione (unità della ripetizione). In 
essa, ogni filo deve avere almeno due intrecci. Nella progettazione dei tessuti, a differenza di quanto avviene per la decorazione a stampa, è di fondamentale importanza considerare e progettare la sequenza degli intrecci. Le loro intersezioni, o meglio le sovrapposizioni alternate, riescono a generare una grande quantità di disegni superficiali che vanno dalle partiture modulari di tipo geometrico, a disegni di tipo più propriamente decorativo [7]. E interessante notare come una serie di notazioni grafiche convenzionali permettono di definire in fase progettuale le numerose sequenze possibili, note come trame o strutture tessute. In particolare, il metodo più comunemente accettato in tutto il mondo prevede l'uso di segni su carta a quadretti. Ogni quadrato rappresenta una posizione o un punto in cui un filo di ordito e un filo di trama si incrociano. L'annerimento di un quadrato indica che un filo passa sopra l'altro [Watson 1921, p. 2] e in particolare che un filo di ordito passa sopra un filo di trama. Un quadrato vuoto rappresenta invece un filo di trama su un filo di ordito. L'annerimento in colonna verticale di due o più quadrati adiacenti rappresenta un ordito che passa su due o più fili di trama.

Già dall'annotazione grafica è possibile intravedere il lavoro di strutturazione dei motivi e le caratteristiche della ripetizione.

Si può facilmente osservare come gli schemi grafici sottesi alla definizione di un tessuto siano esempi di strutture modulari concepite con una logica analoga a quella del disegno a stampa, in cui la reiterazione di una unità di base, secondo precise sequenze matematico geometriche, determina la composizione del pattern letto nella sua interezza. Anche nell'ordito, dunque, "alla base del sistema compositivo si ha il rapporto, cioè la struttura geometrico-cromatico-formale che, adeguatamente combinata in un assieme compositivo di moduli

Fig. 4. Simmetrie caratteristiche delle 17 classi di pattern all-over (immagine tratta da:Thomas, Hann 2007, p. 17).

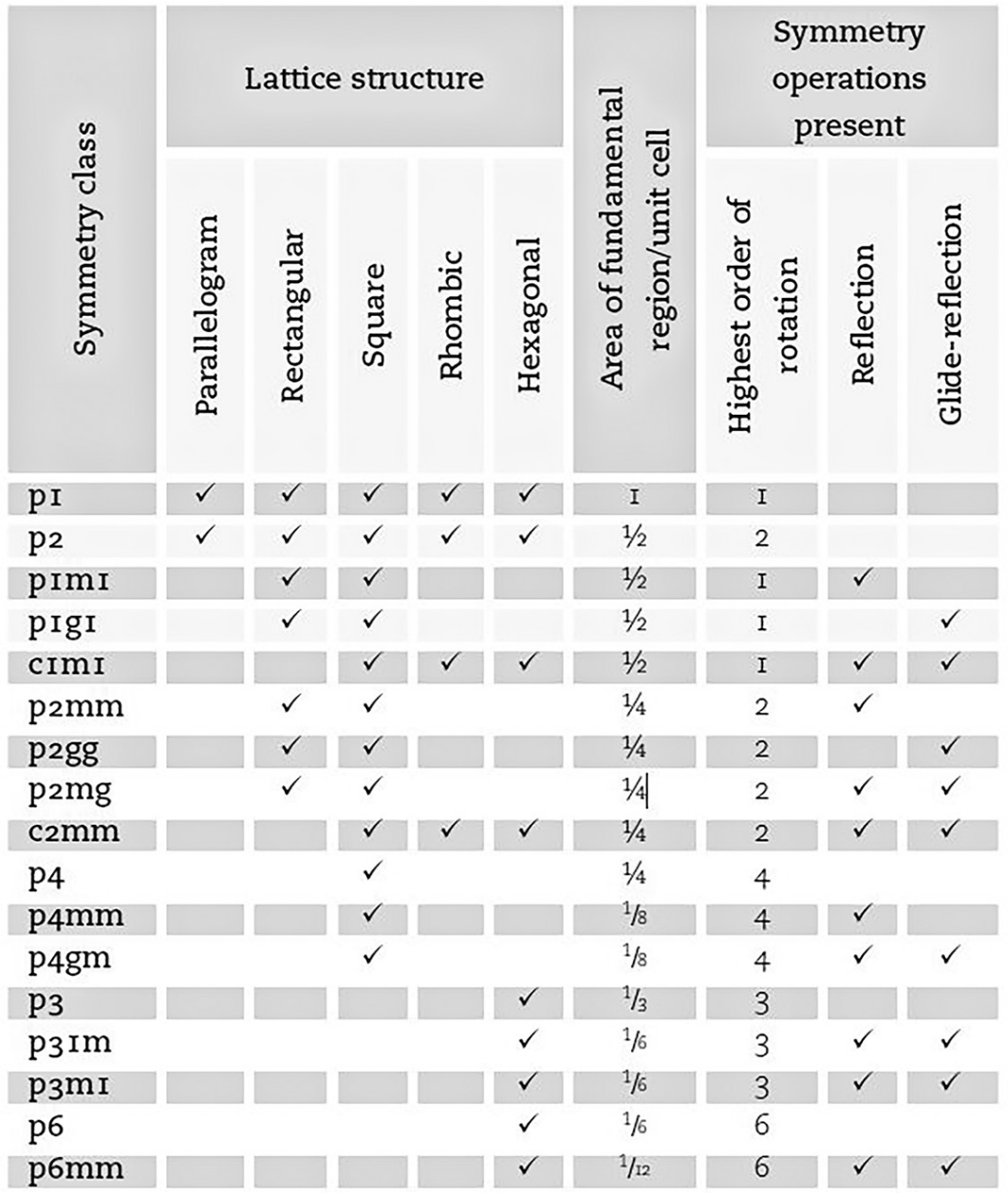


adiacenti e compenetrantisi tra loro si ripete per l'intera estensione del tessuto" [De Paolis 20 I2, p. 240] o della superficie da coprire.

Pertanto, la bellezza di un pattern non è tanto dovuta alla natura dei suoi elementi quanto al giusto uso di essi come unità in uno schema ritmico [Horne 2000].

Nondimeno, nell'esplorare le relazioni tra arte tessile e geometria, occorre considerare le possibilità e gli effetti delle texture tridimensionali. Tradizionalmente ottenute attraverso le operazioni di tessitura jacquard o di immagliatura con intrecci in trama o in catena, oggi grazie ai procedimenti innovativi, alla stampa 3D e ai metodi di progettazione parametrica, i tessuti possono essere costruiti in vario modo: come alterazione di strutture bidimensionali, come tessuti tridimensionali veri e propri, come maglieria o come non-tessuti ottenuti tramite processi additivi che simulano le morfologie di crescita biologica. Lo studio della configurazione e della geometria dei tessuti 3D in recenti lavori di ricerca [Chen 20 I5] ha condotto anche a una loro classificazione in quattro categorie: solido, cavo, a conchiglia e nodale. Su queste si fondano articolazioni superficiali del tutto nuove, con risultati impossibili da ottenere attraverso i tradizionali processi di tessitura. Tassellazioni e pattern di tipo alveolare, poligonale, a shed etc. costituiscono elementi ricorrenti di una nuova estetica - di fatto strettamente legata a diversificati campi di impiego che richiedono specifiche caratteristiche fisico-meccaniche - i cui principi di sviluppo parametrico ottenuti attraverso software infografici, sembrano rievocare la morfologia microscopica delle strutture naturali.

II ricorso a parametri e algoritmi permette di trasporre sulla superficie del tessuto quei principi di aggregazione e quei meccanismi di crescita biologica che rafforzano il forte legame tra numero e forma e in tal caso, ancora, tra arte tessile e matematica. Come scritto da Thompson "l'armonia del mondo si manifesta nella forma e nel numero, e il cuore e l'anima e tutta la poesia della filosofia naturale si incarnano nel concetto di bellezza matematica. Tale è la perfezione della bellezza matematica che ciò che più è aggraziato e regolare, insieme è più utile e perfetto" [Thompson 20 I6, pp. 350, 35 I]. La decorazione come mimesi della natura riporta l'armonia del numero anche nell'arte tessile in cui geometria, struttura e forma restano sottese al linguaggio compositivo e possono sostenere in maniera significativa anche la stessa intuizione artistica.

Fig. 5. Esempi di alcuni pattern ottenuti sfruttando le simmetrie pl, p2 e p4.
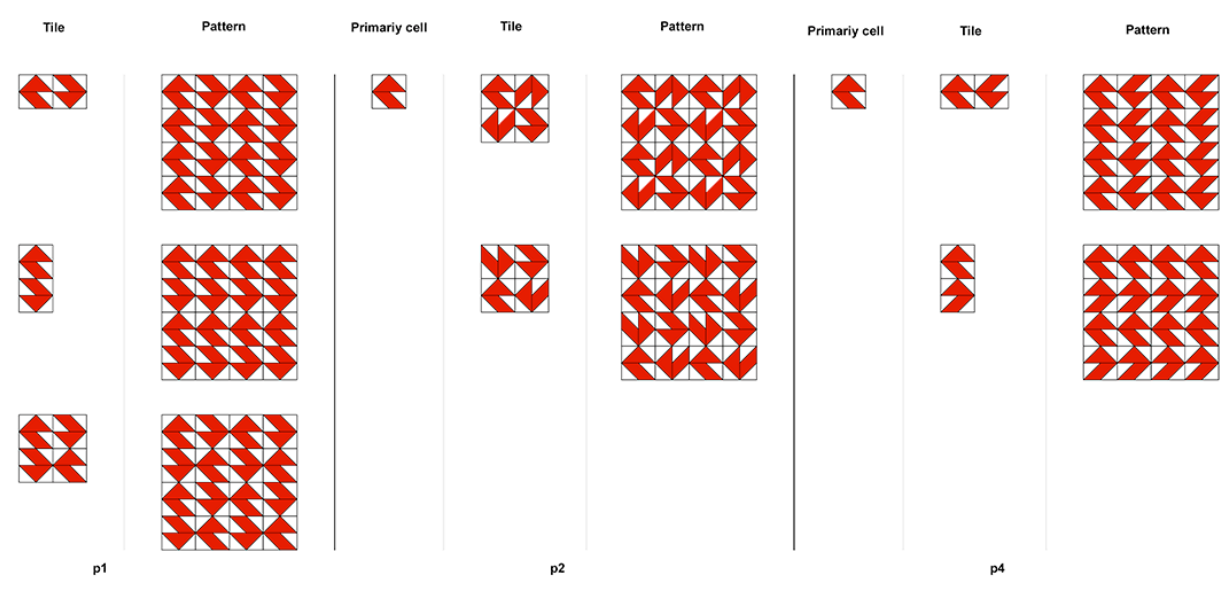

\section{Conclusioni}

Il presente studio ha inteso mettere in evidenza le significative relazioni tra l'arte della decorazione tessile e la geometria. Si tratta in molti casi di problemi geometrici che percorrono in maniera trasversale arti visive, cultura visuale, design, scienza e matematica, e che in questo lavoro sono stati recuperati, enunciati e discussi come possibili elementi di stimolo per la didattica e la ricerca. 
Fig. 6. II Design di patterns ornamentali per tessili su griglia quadrata ed esagonale (immagini tratte da: Ste estratti dalle tavole III e p. 16 e p. 23).

Fig. 7. William Morris, Disegno per un appendiab ti ricamato, prodotto da Morris \& Co., Inghilterra 877 (archivi Victoria and Albert Museum: <http:// collections.vam.ac.uk/ item/O|26|697>)

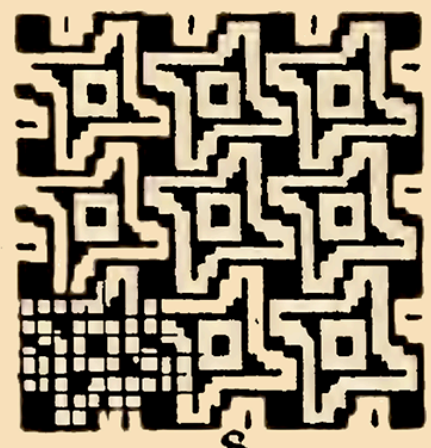

$\delta$.

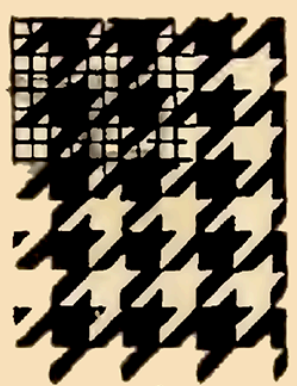

9.

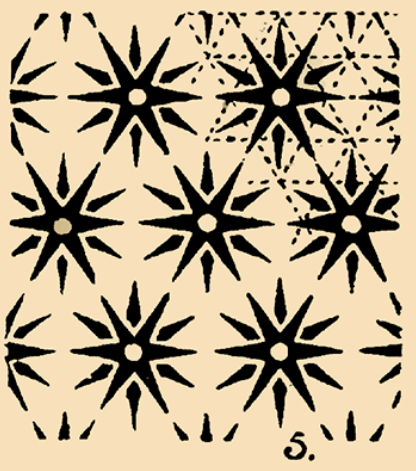

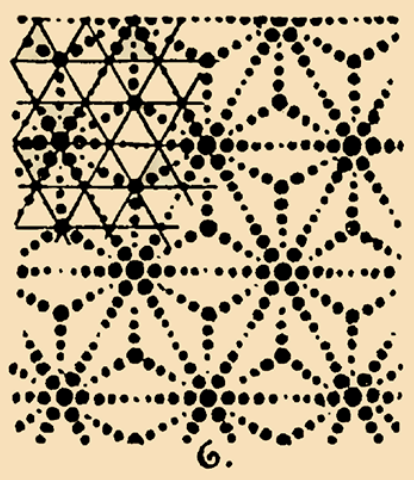

$6:$

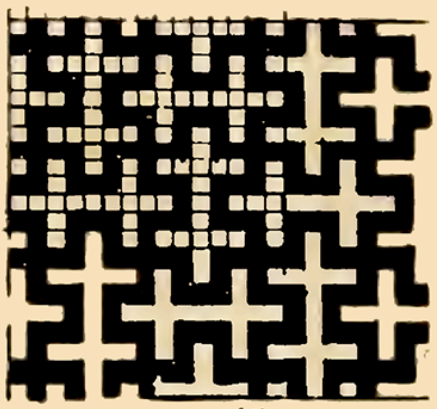

10.

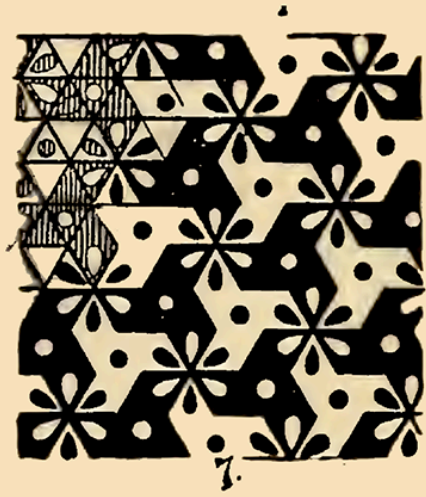

Negli ultimi anni infatti, in Italia come in Europa, i corsi di studio incentrati sulle discipline della moda, un tempo prerogativa di scuole di settore - spesso orientate alla formazione e alla qualificazione professionale di disegnatori progettisti per le imprese produttrici di beni e servizi - hanno trovato sempre più spazio sia nelle accademie di belle arti che nelle università, a fronte, invero, di una significativa domanda. Le ricadute in ambito didattico di tale passaggio sono state tuttavia notevoli, dovendo numerose discipline recuperare quei fondamenti teorici spesso trasversali e trascurati nella didattica professionale, ma di estrema utilità in una formazione universitaria i cui obiettivi guardano in maniera specifica anche alla ricerca e a una progettualità innovativa nel settore.

In particolare, nel campo del disegno tessile, dove la struttura e la forma della decorazione assumono un ruolo chiave, si è spesso rilevato un vuoto teorico con la conseguente necessità di rimandare a una letteratura matematica in molti casi di difficile comprensione. L'importanza di ricondurre alla disciplina del disegno tessile alcuni concetti di base della geometria permette sicuramente di semplificarne l'astrattezza simbolico-terminologica e di trasferire tali conoscenze in maniera efficace a coloro che si avvicinano a tale ambito all'interno dei nuovi curricula, consentendo un approccio grafico-progettuale consapevole.

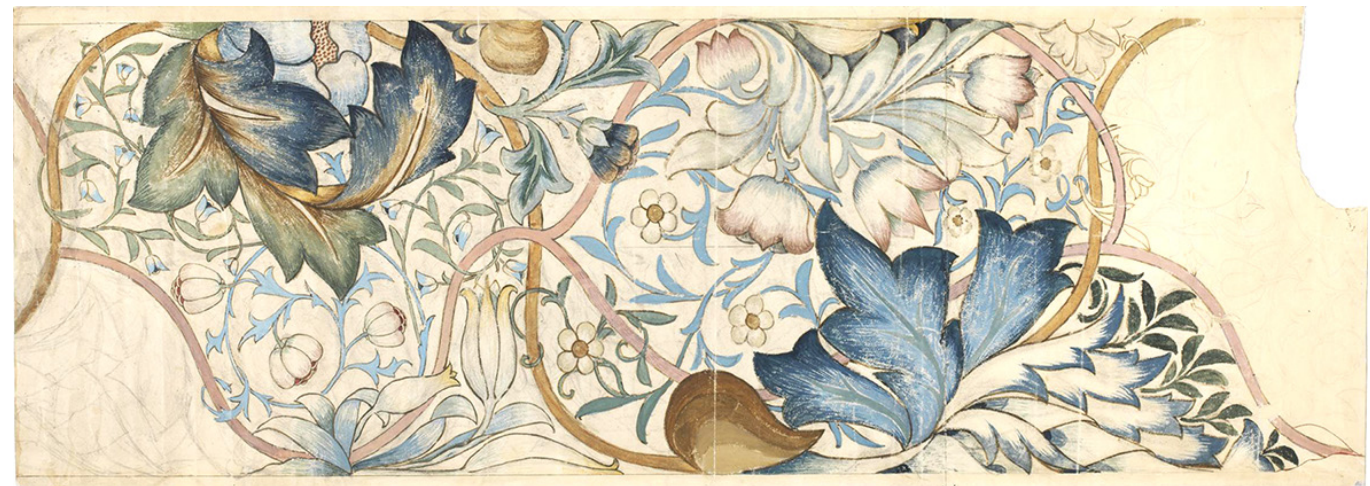


Fig. 8. Variazioni di pattern tessili a saia cosiddetti "Shepherd's-check pat"tern" A sinistra (lettere $\mathrm{K}-\mathrm{R})$ esemplificazione grafica della tessitura su carta quadrettata; a destra (lettere K-R) campioni di tessuto corrispondenti; (immagini tratte da:Watso
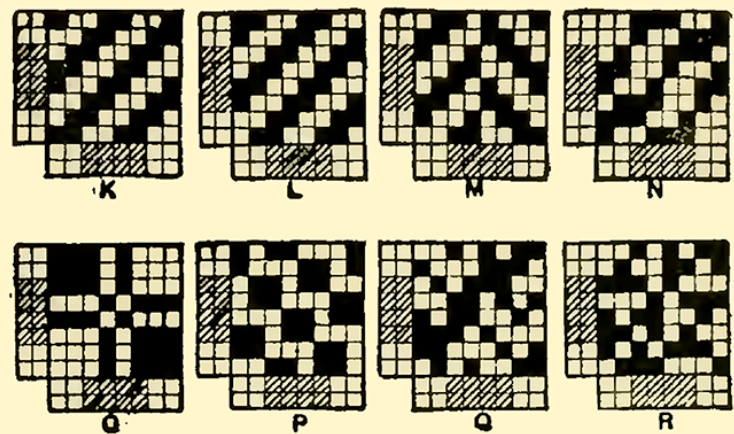
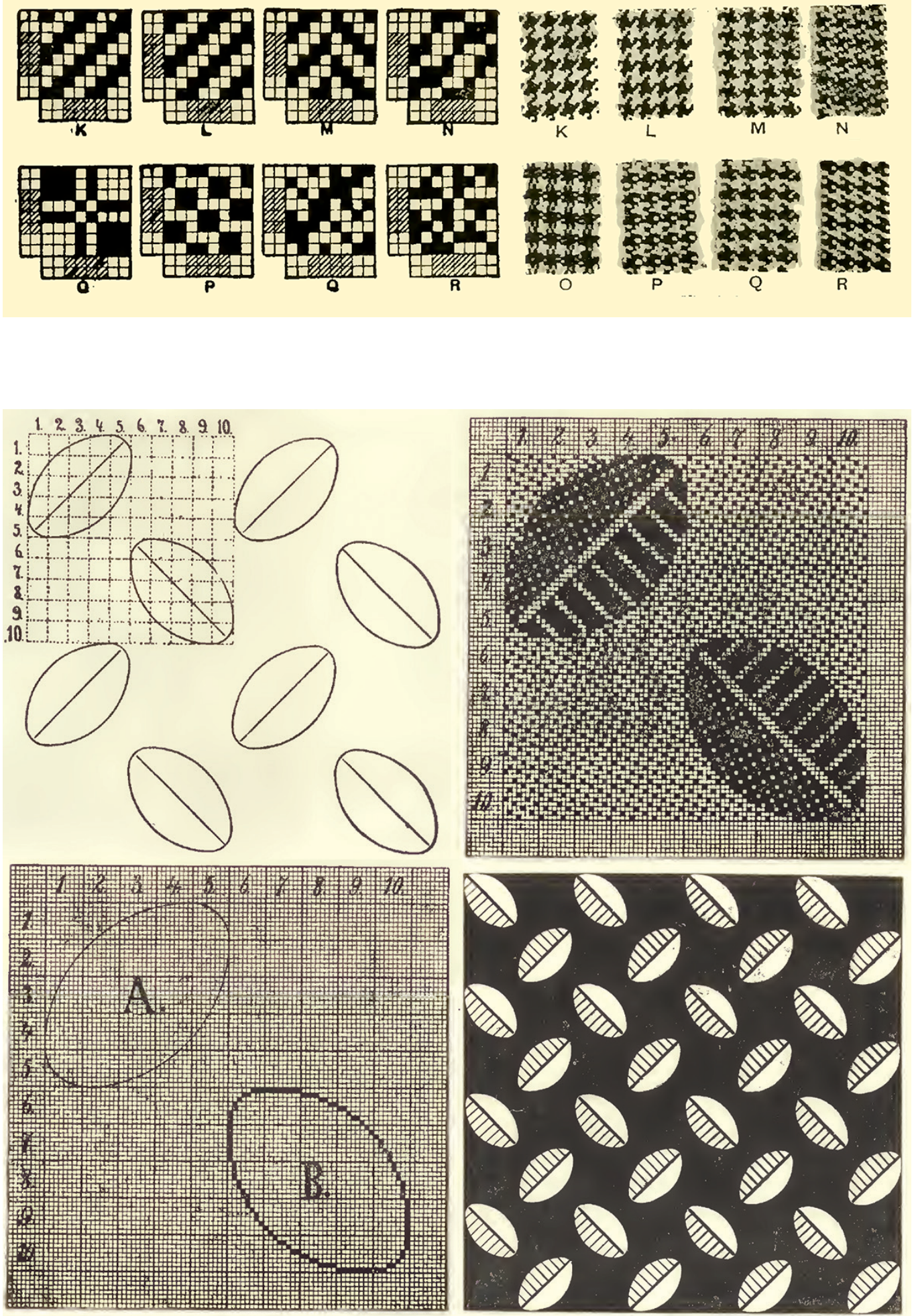

ig. 9. Illustrazione del processo dallo schizzo a disegno tecnico su carta al tessuto finale (immagipp. | | 5,116$)$. 
Fig. 10. Aleksandra Gaca, tessuto con pattern alveolare 3D (immagine tratta da aleksandragaca. eu)

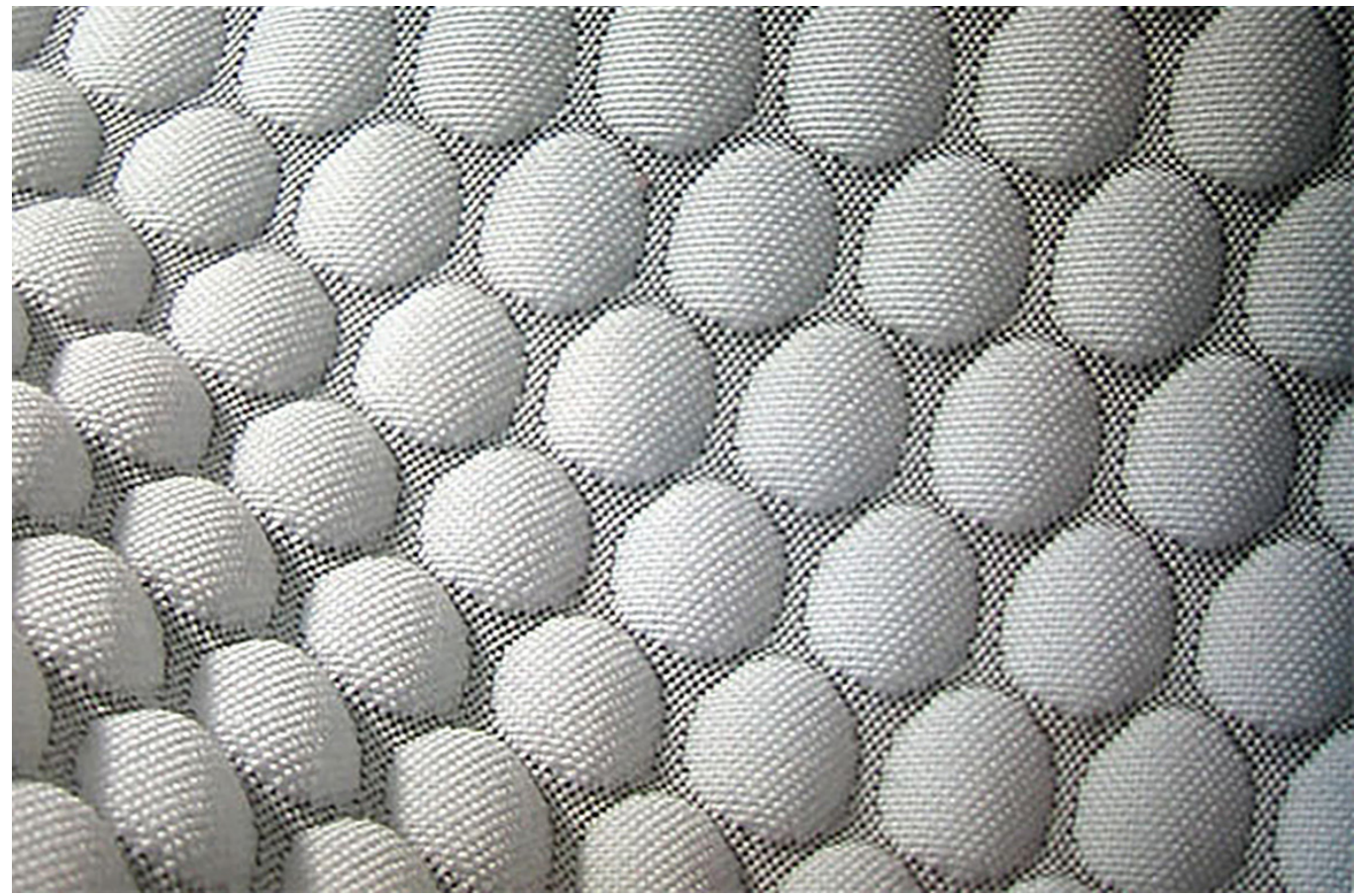

Fig. I I. Lim Kae Woei ed Elena Low, tessile stampa 3D ottenuto attraverso modellazione solida parametrica. Immagine tratta da: http:// www.xyzworkshop.com flv_portfolio/singapore-2 (foto di Memento inc.).
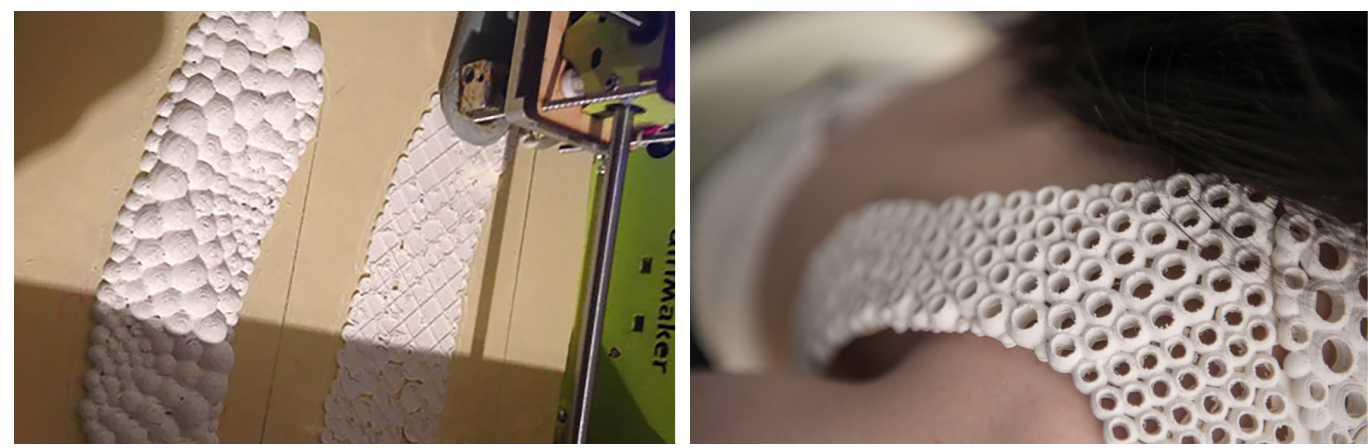

Note

[I] Franz Sales Meyer (1849-1927) fu docente presso la Großherzoglichen Badischen Kunstschule (Grand Ducal School of Applied Arts) di Karlsruhe. II suo testo Ornamentale Formenlehre del 1886, tradotto in inglese nel 1896 col titolo A Handbook of Ornament, fa seguito a una serie di studi sull'ornamentazione. Tra questi va certamente annoverato il lavoro pioneristico di Owen Jones (1 809- | 874), architetto, designer e teorico di epoca vittoriana, il cui scritto The Grammar of Ornament, pubblicato nel 1856 rappresenta l'opera editoriale a stampa cromatica più completa sulla storia della decorazione [Jones I856].

[2] Meyer individua tre gruppi di ornamentazioni geometriche: a motivi lineari (continuous and ribbon like [bands]), a pannello (enclosed spaces [panels]) e pattern piani indefinitamente estensibili (unlimited flat patterns) [Meyer 1920, p. 3]

[3] A proposito dei pattern piani Hann scrive: "La caratteristica principale di un pattern è la ripetizione (o traslazione) di un motivo a una data distanza sul piano. Se la ripetizione è continua in una sola direzione, tra due linee (reali o immaginarie), in pattern ottenuto può essere definito border pattern oppure motivo a sviluppo lineare, fregio o disegno monodimensionale. Quando la ripetizione avviene secondo due direzioni indipendenti, coprendo il piano, il pattern risultante può essere indicato come all-over, esso comprende anche i wallpaper pattern, periodic pattern o crystallographic pattern" [Hann 2003, p. 55].

[4] Tali strutture reticolari prendono anche il nome di "strutture di Bravais" ereditando il nome dal fisico francese Auguste Bravais ( $8 \mid$ | - | 863) che per primo le classificò in un suo esaustivo studio sui cristalli del | 848. Egli ne identificò 5 nel piano e 14 nello spazio [Bravais 1949]

[5] I 'motivi' sono anche definiti come 'figure finite' (finite figures), 'figure limitate' (bounded figures) o 'gruppi di punti' (point groups) [Hann 2003, p. 55] 
[6] In relazione al tipo di simmetria che costituisce i motivi simmetrici, essi possono essere classificati usando la notazione cn (c sta per 'ciclico') o dn (d sta per'diedrico'). Quelli ciclici presentano simmetrie rotazionali di ordine n; quelli diedrici presentano n distinti assi di simmetria e simmetrie rotazionali di ordine n [Thomas, Hann 2007, p. I0].

[7] Le possibilità di ottenere una grandissima varietà di disegni sono storicamente legate all'invenzione, nel I804, del cosiddetto "telaio Jacquard", dal nome del suo inventore Joseph Marie Jacquard (I 752- I 854), che rappresenta forse la più rivoluzionaria innovazione nell'arte tessile [Hobsbawn 1996, p. 30]. II telaio Jacquard offriva la possibilità di velocizzare il lavoro di tessitura, di intrecciare con un sol movimento, centinaia di fili con una sola evoluzione (oggi più di l0.000), permettendo la realizzazione di disegni geometrici complessi e di aumentare le dimensioni stesse del tessuto. La sequenza di operazioni era controllata da una serie di schede perforate sostituibili da inserire nella testa del telaio [Posselt I893]. Proprio per tale motivo il telaio Jacquard è stato considerato una innovazione strettamente legata alla storia del computer [Essinger 2004].

\section{Riferimenti bibliografici}

Bravais Auguste (1949). On the systems formed by points regularly distributed on a plane or in space. Crystallographic Society of America, Mem. I, translated by Amos I. (Ed. originale Bravais Auguste (1850). Sur les systèmes formés pardes points distribués régulièrement sur un plan au dans l'espace. In Journal de l'École Polytecnique, Cahier 33, tome 19, I850, pp. I- I28).

Chen Xiaogang (ed.). (2015). Advances in 3D Textiles. Cambridge:Woodhead Publishing Limited.

Christie Archibald H. (1910). Traditional methods of Pattern Designing. Oxford: Claredon Press.

Davis Philip J., Hersh Reuben (1986). Descartes' Dream. Brighton: Harvester Press.

Day Lewis F. (1903). Pattern Design. London: B.T. Batsford Ltd.

De Paolis Roberto (20 I 2). Il disegno della superficie: dal tessuto d'arredo al rivestimento di interni. In Rossi Michela (a cura di). II Disegno come Ricerca. Strumenti grafici e modelli rappresentativi per il progetto. Santarcangelo di Romagna: Maggioli.

Essinger James (2004). How a hand-loom led to the birth of the information age. Oxford: Oxford University Press.

Grünbaum Branko, Shephard Geoffrey C. (1987). Tilings and Patterns. New York: Freeman.

Hann Michael A. (2003). The Fundamentals of Pattern Structure. Part I:Woods Revisited. In The Journal of The Textile Institute, 94, I-2, pp. 53-65.

Hobsbawn Eric J. (1996). The Age of Revolution, 1789- 1898. New York:Vintage Books Editions.

Horne Clare E. (2000). Geometric symmetry in patterns and tilings. Cambridge:Woodhead Publishing Ltd.

Jones Owen ( I 856). The Grammar of Ornament. London: Day and Son.

Kappraff Jay (1990). Connections: The Geometric Bridge Between Art and Science. New York: McGraw-Hill.

Kubovy Michael (1994). The perceptual organization of dot lattices. In Psychonomic Bullettin \& Review, I, pp. I 82- 190.

Meyer Franz S. (1920). A Handbook of Ornament. First american Edition. New York: Architectural Book Publishing Company. (Ed. orig. Ornamentale Formenlehre. Leipzig: E.A. Seemann, I886, in folio).

Posselt Emanuel A. ( 1893$)$. The Jaquarde Machine. Philadelphia: Posselt.

Stephenson Charles, Suddards Frank ( 1897). A Textbook Dealing with Ornamental Design for Woven Fabrics. London: Methuen.

Thomas Briony G., Hann Michael A. (2007). Patterns in the Plane and Beyond: Symmetry in Two and Three Dimensions. Leeds: University of Leeds International Textiles Archive.

Thompson D'Arcy W. (2016). Crescita e forma: la geometria della natura. Edizione ridotta a cura di John Tyler Bonner. Milano: Bollati Boringhieri. (Ed. orig. On Growth and Form. An Abriged Edition edited by J.T. Bonner, Cambridge: Cambridge University Press, 1961).

Washburn Doroty K., Crowe Donald W. (|99|). Symmetries of Culture: Theory and Practice of Plane Pattern Analysis. Seattle: University of Washington Press.

Watson William (1921). Textile Design and Colour, Elementary Weaves and Figured Fabrics (second edition). London: Longmans, Green and co.

\section{Autore}

Stefano Chiarenza, Università San Raffaele Roma, stefano.chiarenza@uniroma5.it

Per citare questo capitolo: Chiarenza Stefano (2020). Arte e geometria nel disegno tessile/Art and geometry in textile drawing. In Arena A., Arena M., Brandolino R.G., Colistra D., Ginex G., Mediati D., Nucifora S., Raffa P. (a cura di). Connettere. Un disegno per annodare e tessere. Atti del $42^{\circ}$ Convegno Internazionale dei Docenti delle Discipline della Rappresentazione/Connecting. Drawing for weaving relationships. Proceedings of the 42th International Conference of Representation Disciplines Teachers. Milano: FrancoAngeli, pp. 296-315. 


\title{
Art and Geometry in Textile Drawing
}

\author{
Stefano Chiarenza
}

\section{Abstract}

This article highlights the relationships between textile drawing, art and geometry by emphasizing some key themes, such as symmetry, structure and shape, present both in the surface ornament and the fabric construction itself. Many geometric concepts of great utility in textile design are still relegated to a mathematical literature of difficult interpretation for those involved in fabric design. They often act by exploiting an intuitive awareness of the geometric order. Therefore, the principles and rules underlying the textile drawing and structure are briefly reviewed and discussed, contextualising them in order not only to convey a scientific approach to graphic design but to stimulate a reflection on teaching and research in the discipline.

Keywords

symmetry, pattern, texture, modularity, ornament.

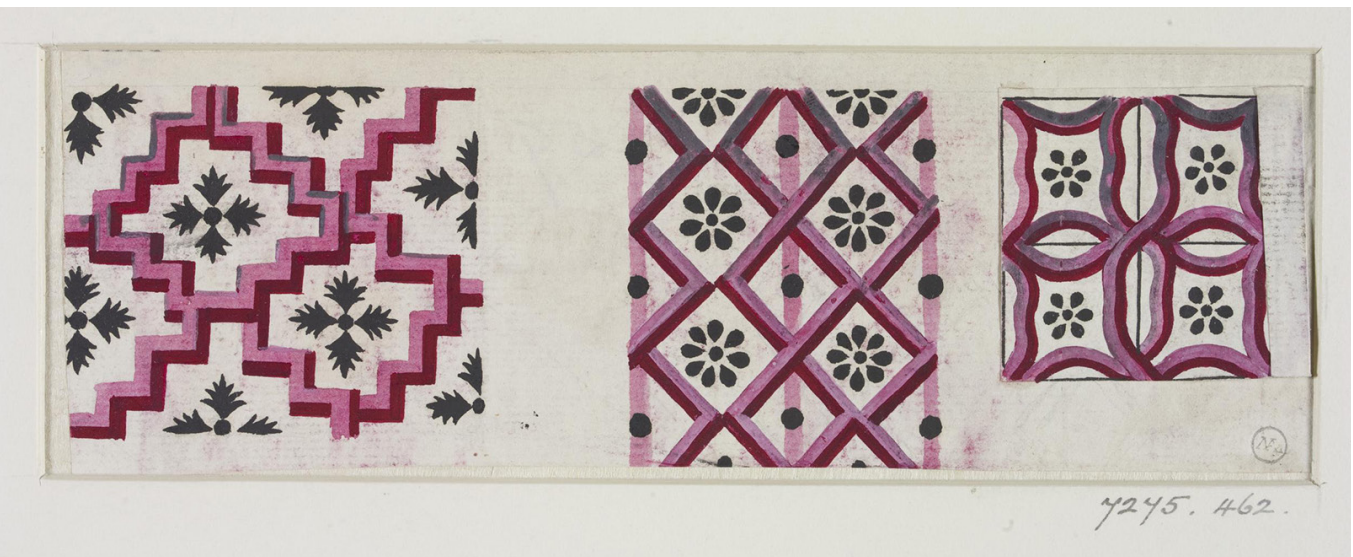




\section{Introduction}

Textile design is an area of particular interest for scholars who deal with design and geometry. In textile design we can find a series of conceptual themes such as those of pattern, structure, shape and proportion which, if on the one hand are basic problems of some sciences -such as mathematics and crystallography- on the other hand appear closely related to graphic design and decorative arts in general. Design and ornament have always found wide inspiration in the balanced and complex forms of nature. From the harmoniousness of macroscopic manifestations to the beauty of microscopic ones, derived from a rigorous mathematical order, these show, upon careful observation, the close link between art and science. The natural attraction towards some forms is actually linked to the presence of regular basic structures on which a series of configurative superstructures are declined with infinite and unpredictable variations. This characteristic constitutes the most evident concept present in textile design. As Horne notes, "such a relationship between a basic formal structure and the individuality of stylistic approaches to its decoration forms a framework for the construction of regularly repeating designs" [Horne 2000, p. I].

The problem of structure and regularity in textile art can actually be investigated from two points of view. One, the subject of the first paragraph, concerns the fabric surface printing. The other, examined in the subsequent paragraph, concerns rather the fabric weave, that is how the threads are intertwined. The two aspects, evidently with common and superimposed traits, highlight the differences between patterns and textures.
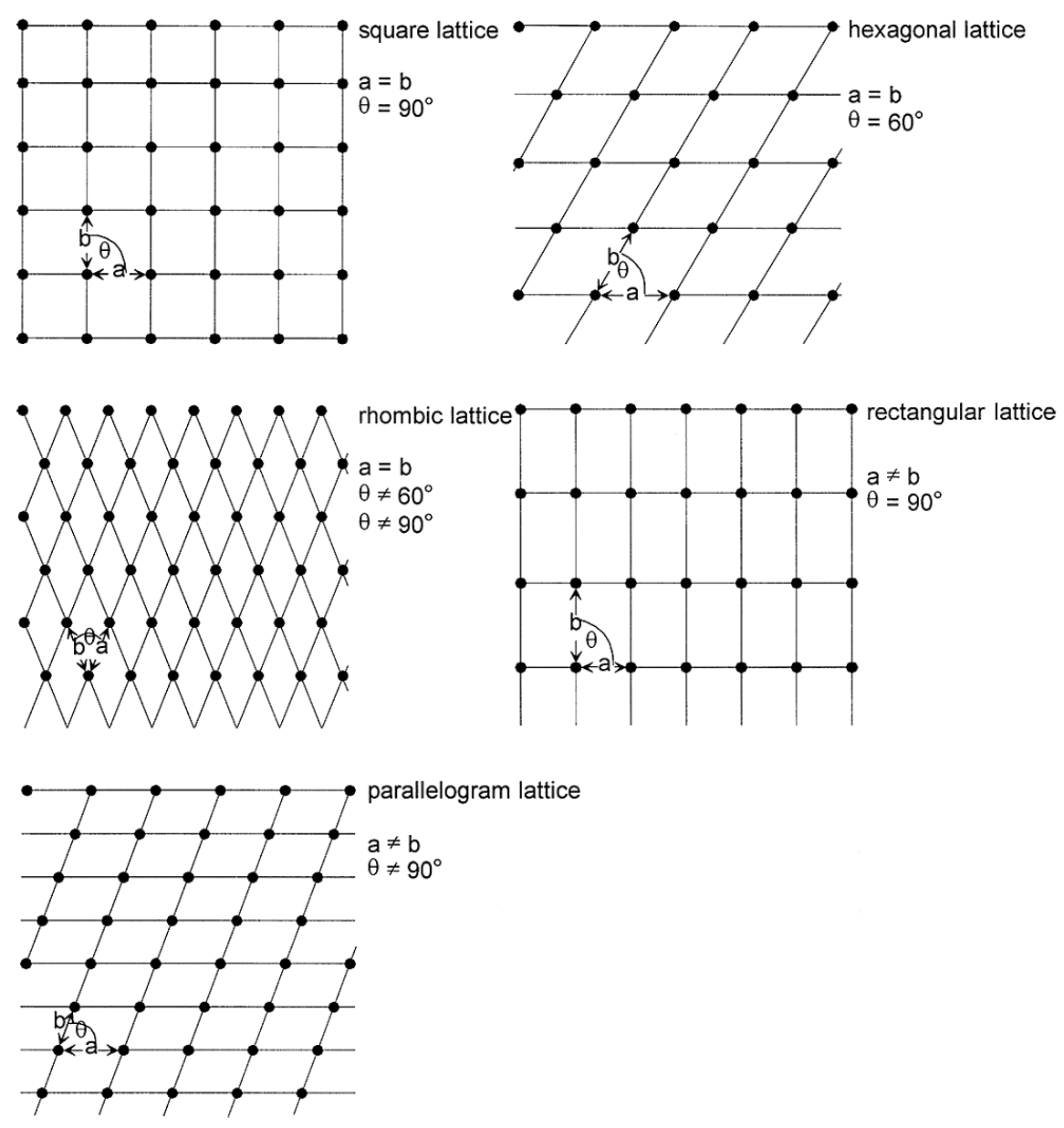


\section{Structure, symmetry and invention in printed decoration}

The decoration of a textile surface is essentially based on the definition of a pattern whose fundamental assumptions are those of structure and symmetry. Regarding the structure, Meyer, in one of the first significant manuals on ornamentation [I], considers the presence of subsidiary networks underlying the design, based on geometries of various nature, but frequently structured on square and equilateral triangle. This network acts as a rule for the repeating composition [Meyer 1920, pp. 3, 4].

$\mathrm{He}$ actually anticipates a series of subsequent studies that highlight how, in all drawings based on repetition, an implicit grid of points defining the basic units (or modules) of the pattern is always recognizable [Stephenson, Suddards 1897; Christie 1910; Day 1903]. Although the compositions may be of several types [2], the structure assumes a key role in the printed motifs in which a single unit is repeated to cover an entire surface (better known as all-over [3]). These are characterized by modular decorative combinations which, although falling within a unitary frame, are never bound neither by the shape of the latter nor within that specific area, contemplating the possibility of endless repetition. That repetition occurs in all directions of the plane, i.e. vertically, horizontally or diagonally.

In general, it is possible to identify, on the plane, only five distinct types of lattice units [Grünbaum, Shephard 1987, p. 262; Bravais 1949, pp. 27, 28] that can be used to generate the different types of grids: parallelograms, rectangles, rhombuses, squares and hexagons [4]. Specifically, these are networks of points that determine the arrangement and movement of the basic motifs characterizing the all-over.

If the structure represents, therefore, one of the fundamental aspects of a pattern [Washburn and Crowe 199 I], a key role in the composition is also played by symmetry, meaning this principle in an extended way, that is inclusive of all the isomorphic transformations on the plane such as translation, rotation, reflection and glide reflection.

Surely, in the realization of two-dimensional schemes on printed fabric, it is easy to find the systematic exploration of different groups of symmetry and to find out how purely mathematical operations are traced back to artistic activity. Kappraff writes that "nowhere is this tension between artists and their art more evident than with regard to the issue of symmetry" [Kappraff 1990, p. 405].

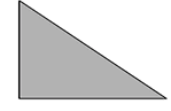

a)

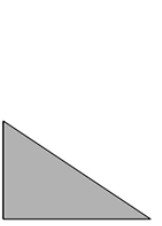

c)

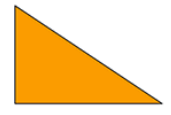

g. 2. The four symmetry operations: a) translation b) rotation, c) reflection, d) glide-reflection.

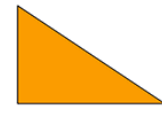

b)
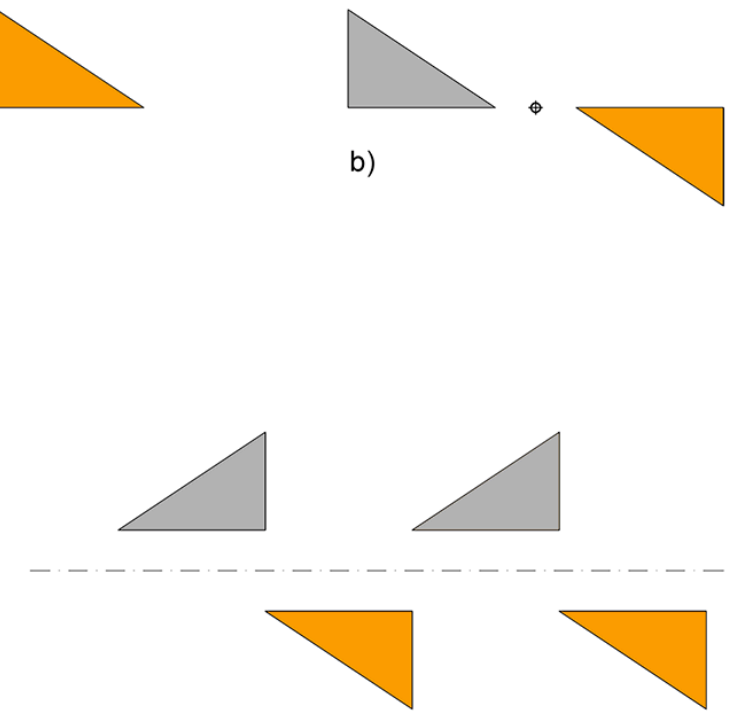

d) 
Motifs [5] are the building blocks of each repeating pattern [Hann 2003]. They can be symmetrical or asymmetrical. They are symmetrical when characterized by the presence of two or more parts having the same shape, size and content [6]. They are asymmetrical when comprised of a single unit that cannot be geometrically divided into two or more equal parts. Translation represents the most common transformation underlying the repetition of a motif. The combination with one or more of the other plane isometries allows generating a total of 17 pattern classes.

In particular, there are four classes with no rotational symmetry and based on translation, reflection, glide reflection or combinations of them; five classes which exploit -in addition to the isometries already mentioned- also rotation $\left(180^{\circ}\right)$; three classes, on an exclusively hexagonal lattice, also based on rotation $\left(120^{\circ}\right)$; three classes, based on a square lattice, which exploit rotation of $90^{\circ}$; finally, two classes on hexagonal lattice, which with reflection and glide reflection, use $60^{\circ}$ rotation. Each of them is based on one of the five Bravais lattice structures. The combination possibilities, therefore, allow the creation of extremely varied patterns. These are also influenced by the choice of the motif that is capable of influencing, often significantly, the perceptual organization. In other words, the motif and its structure in the pattern can highlight some isometries rather than others. As was indeed observed in a specific study "each type of wallpaper pattern is defined by its lattice type and a list of isometric transformations (i.e., transformations that preserve distance: translation, rotation, reflection, and glide reflection) that map the pattern onto itself. When different perceptual organizations are induced in wallpaper patterns by different motifs, different isometries become salient to the observer. As a result, formally isomorphic wallpaper patterns can appear to be of different types, and formally different wallpaper patterns may appear to be similar" [Kubovy 1994, p. 190]. On these assumptions, it is also possible to refer to the textile design what Davis and Hersh underlined regarding the implicit relationships between art and mathematics or that "through intuition, the artist is often an unconscious mathematician, discovering, rediscovering, and exploring ideas of spatial arrangement, symmetry, periodicities, combinatorics and transformations and discovering, in a visual sense, theorems of geometry" [Davis, Hersh 1986, p. 43].

Fig. 3. On the left: design for a printed chintz textie. British, c. 1760s - 1770 (source: Victoria and Albert Museum archives (n) ac.uk/item/OIO15840>) On the right: Glide-reflexion scheme of the textile drawing.
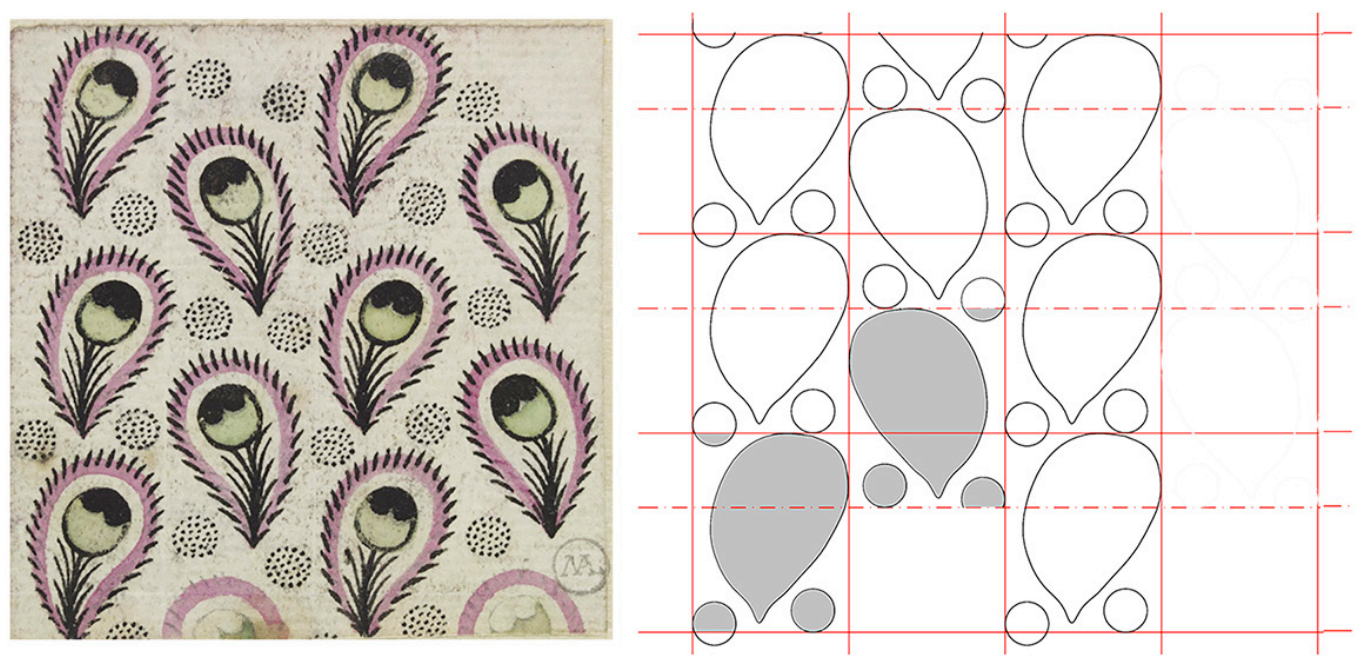

\section{Modularity in the weave}

The constituent structure of the fabric represents another connecting element between textile design, geometry and mathematics. The weave of a fabric, or the way in which the warp and weft threads are intertwined, is what characterizes the texture and drawing regardless of the print. In the vast majority of fabrics, the order in which the threads are intertwined repeats itself periodically according to the weft (horizontal) and warp (vertical) 
directions. In the vast majority of fabrics, the order in which the threads are intertwined repeats itself periodically according to the weft (horizontal) and warp (vertical) directions. The smallest, single recurring part is known as repetition (repetition unit). In it, each thread must have at least two weaves. In the fabric's design, unlike what happens for printed decoration, it is of fundamental importance to consider and design the sequence of the weaves. Their intersections, or rather the alternating overlaps, manage to generate a large number of surface drawings ranging from modular scores of a geometric type to more properly decorative drawings [7]. It is interesting to note how a series of conventional graphic notations allow defining in the design phase the numerous possible sequences, known as textures or woven structures. In particular, the most commonly accepted method in the world involves the use of signs on squared paper. Each square represents a position or point where a warp and weft thread cross. The blackening of a square indicates that one thread passes over the other [Watson 1921, p. 2] and in particular that a warp thread passes over a weft thread. Instead, an empty square represents a weft thread on a warp thread. The blackening of two or more adjacent squares in a vertical column represents a warp that passes on two or more weft threads.

Already from the graphic annotation, it is possible to glimpse the work of structuring the patterns and characteristics of the repetition.

It can easily be seen that the graphic patterns underlying the definition of fabric are examples of modular structures conceived with a logic similar to that of the printed drawing, in which the reiteration of a basic unit, according to precise mathematical geometric sequences, determines the composition of the pattern read in its entirety. Also in the warp, there-

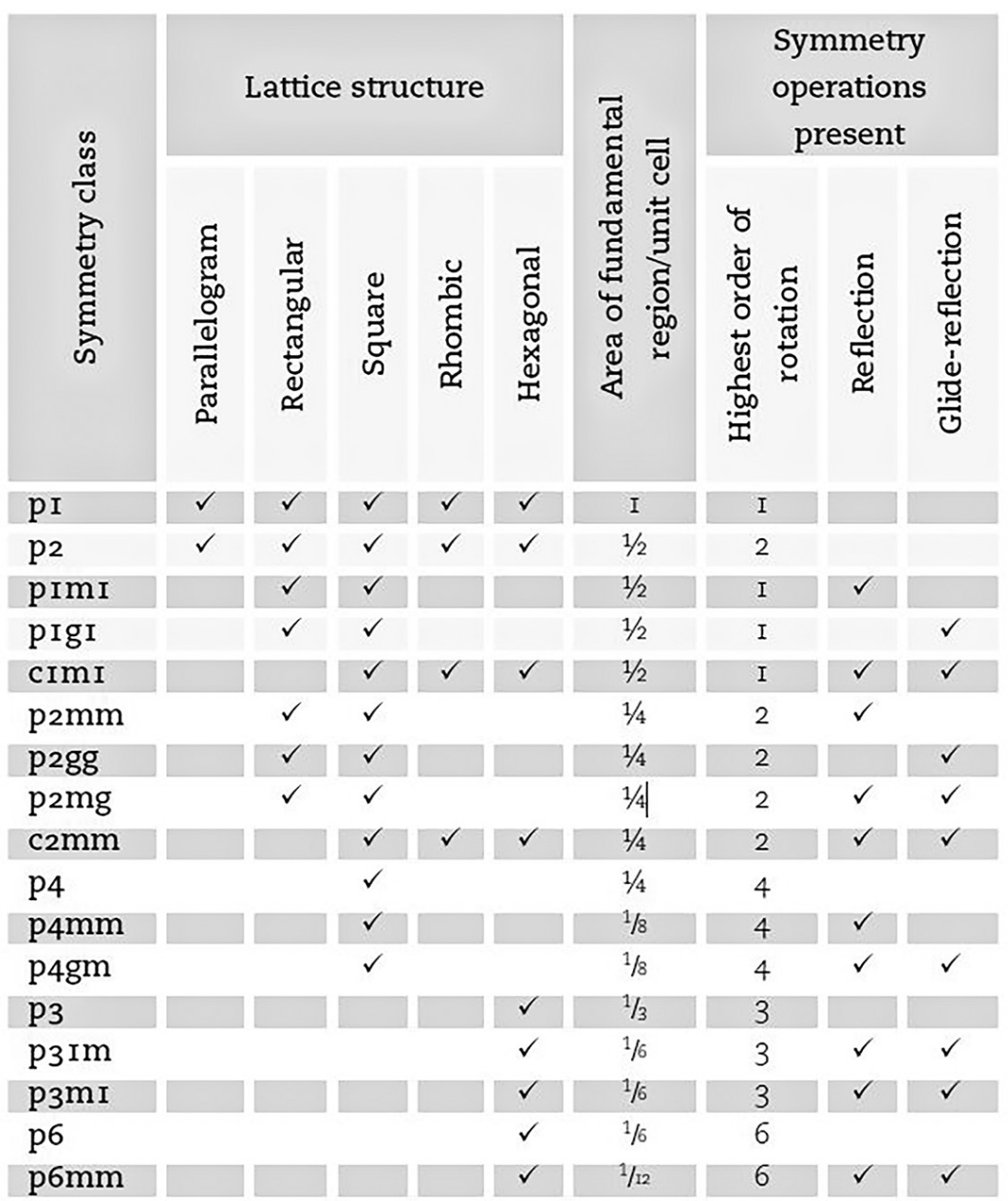


fore, "at the basis of the compositional system, there is the relationship, that is the geometric-chromatic-formal structure which, properly combined in a compositional assembly of adjacent modules and interpenetrating between them, is repeated for the entire extension of the fabric" [De Paolis 2012, p. 240] or of the surface to be covered.

Therefore, the beauty of a pattern is not so much due to the nature of its elements as to the right use of them as a unit in a rhythmic scheme [Horne 2000].

Nonetheless, in exploring the relationships between textile art and geometry, it is necessary to consider the possibilities and effects of three-dimensional textures. Traditionally obtained through jacquard weaving or weaving with weft or chain weaving, today thanks to innovative processes, 3D printing and parametric design methods, fabrics can be constructed in various ways: as alteration of two-dimensional structures, as real three-dimensional fabrics, as knitwear or as nonwowen fabrics obtained through additive processes that simulate the morphologies of biological growth. The study of the configuration and geometry of 3D fabrics in recent research works [Chen 20 I5] has also led to their classification into four categories: solid, hollow, shell and nodal. Completely new surface structures are based on these, with results impossible to obtain through traditional weaving processes. Alveolar, polygonal and shed tessellations and patterns etc. are recurring elements of a new aesthetic -in fact closely linked to diversified fields of use that require specific physical-mechanical characteristicswhose principles of parametric development obtained through infographic software, seem to evoke the microscopic morphology of natural structures.

The use of parameters and algorithms allows transposing on the surface of the fabric those principles of aggregation and those mechanisms of biological growth that reinforce the strong link between number and shape and in this case, again, between textile and mathematical art. As written by Thompson "The harmony of the world is made manifest in Form and Number, and the heart and soul and all the poetry of Natural Philosophy are embodied in the concept of mathematical beauty. The perfection of mathematical beauty is such [...] that whatsoever is most beautiful and regular is also found to be most useful and excellent" [Thompson 2016, pp. 350, 35 I]. Decoration as mimesis of nature brings the harmony of the number also in the textile art in which geometry, structure and shape remain underlying the compositional language and can significantly support even the same artistic intuition.

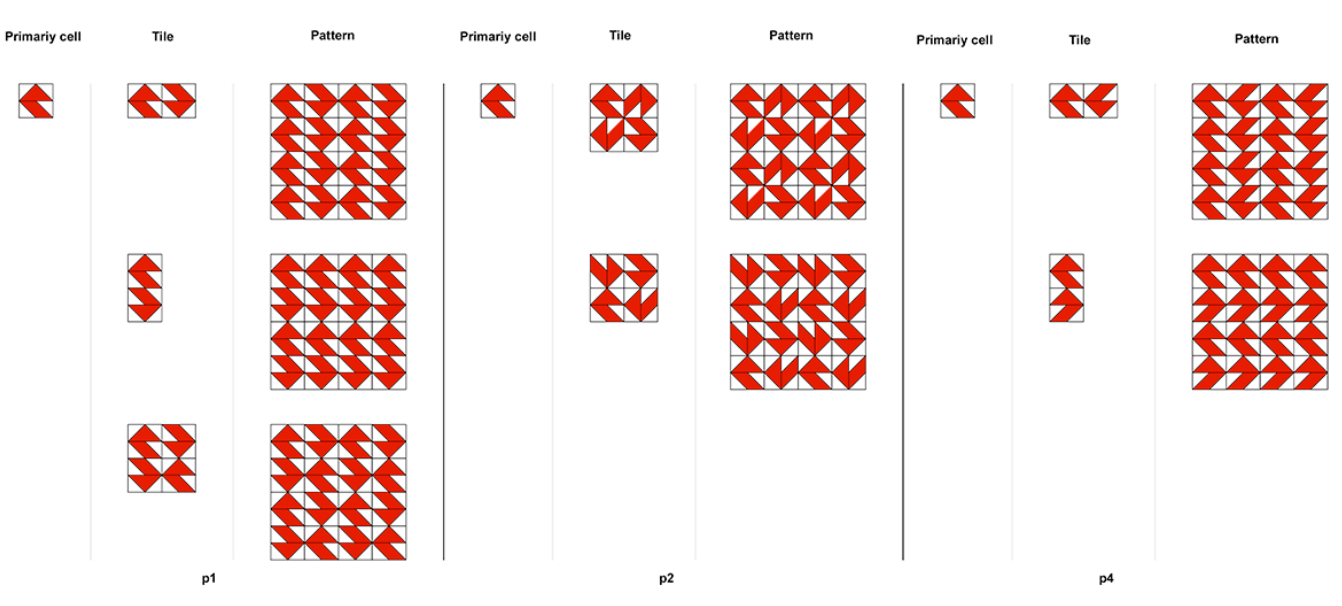

\section{Conclusions}

This study aimed to highlight the significant relationships between the art of textile decoration and geometry. In many cases, these are geometric problems that cross the visual arts, visual culture, design, science and mathematics, and which in this work have been recovered, enunciated and discussed as possible stimulating elements for teaching and research. In recent years, in Italy as in Europe, courses of study focused on the fashion's disciplines 
Fig. 6. Design pattern based upon square and hexagon (Images from: Stephen, Suddards 1897 plates III and V, p. 16 and

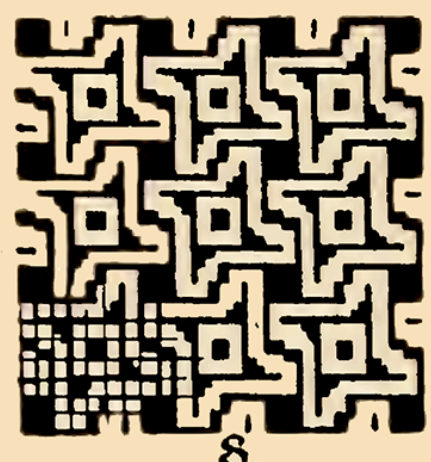

$\mathcal{8}$.

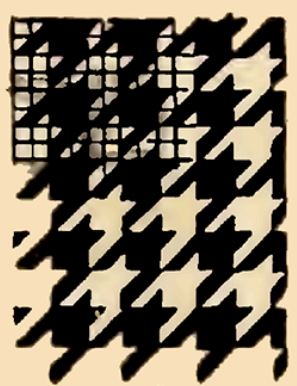

9.

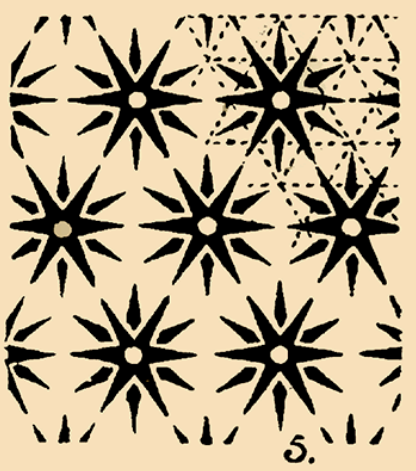

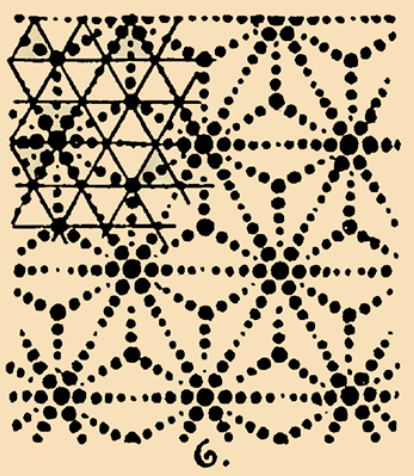

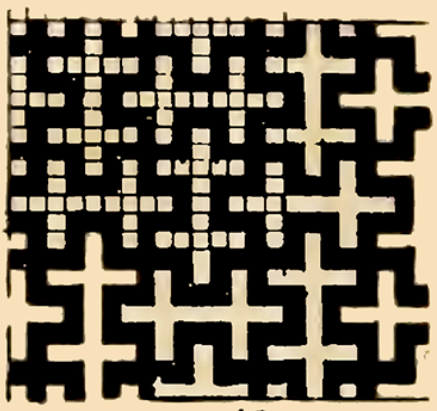

10.

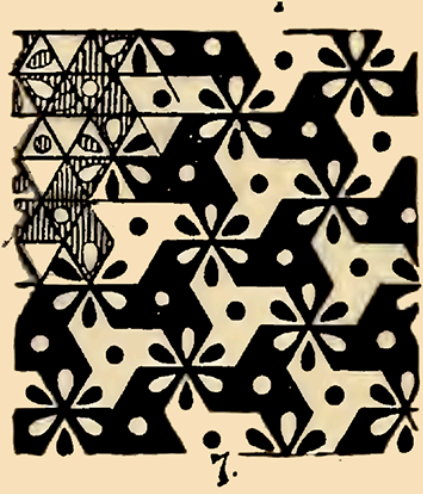

-once the prerogative of technical schools often oriented towards the training and professional qualification of designer for companies producing goods and services- have found more and more space both in fine arts academies and in universities, indeed, as a result of significant demand. The repercussions in the didactic field of this passage have however been remarkable since numerous disciplines have to recover those theoretical foundations which are often transversal and neglected in professional teaching, but extremely useful in a university education whose objectives also specifically focus on research and innovative planning in the field.

In particular, in the field of textile drawing, where the structure and shape of the decoration play a key role, a theoretical void has often been found with the consequent need to refer to mathematical literature in many cases difficult to understand. The importance of bringing back to the discipline of textile design some basic concepts of geometry certainly allows to simplify their symbolic-terminological abstractness and to transfer this knowledge effectively to those who approach this area within the new curricula, allowing a conscious graphic-design approach.

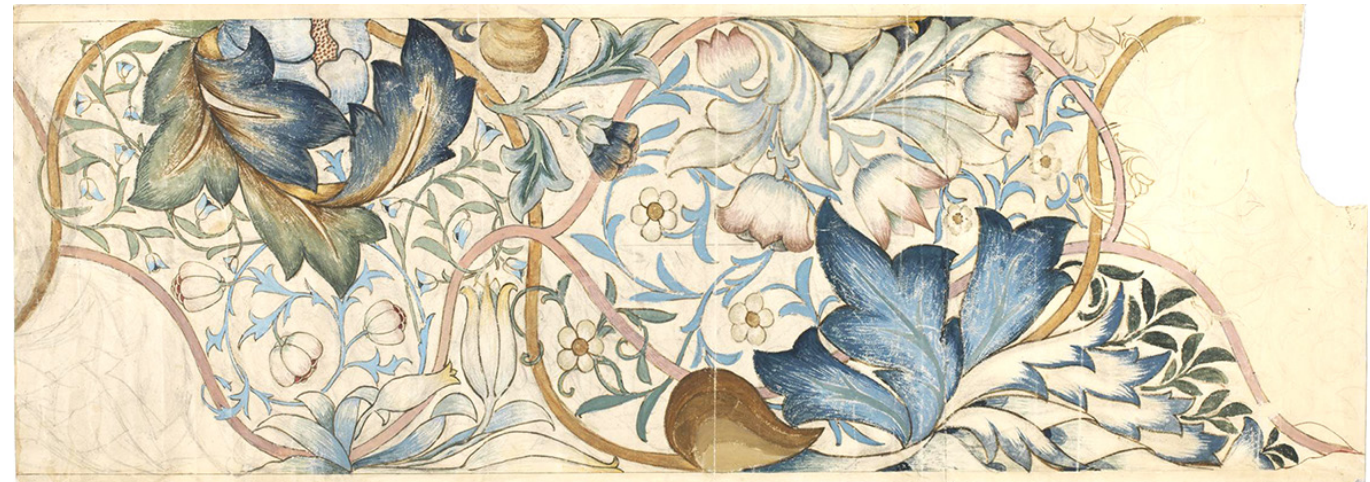

Fig. 7. William Morris, Design for an embroidered wall-hanging, manufactured by Morris \& Co., British, 1877. Victoria and Albert Museum archives: <http:/ collections.vam.ac.uk 
Fig. 8. Shepherd's-check patterns style variations. On the left (letters K-R) examples represented on paper in flat view (letters K-R) corresponding fabric samples;

(images from: Watson 1921, pp. I56, I57).
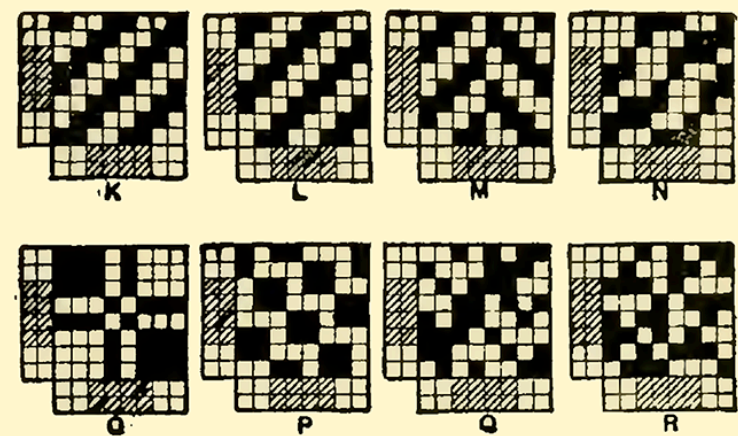
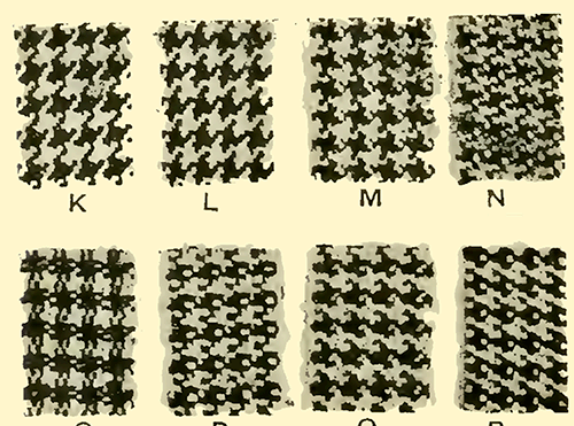

0
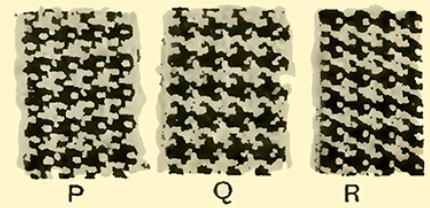
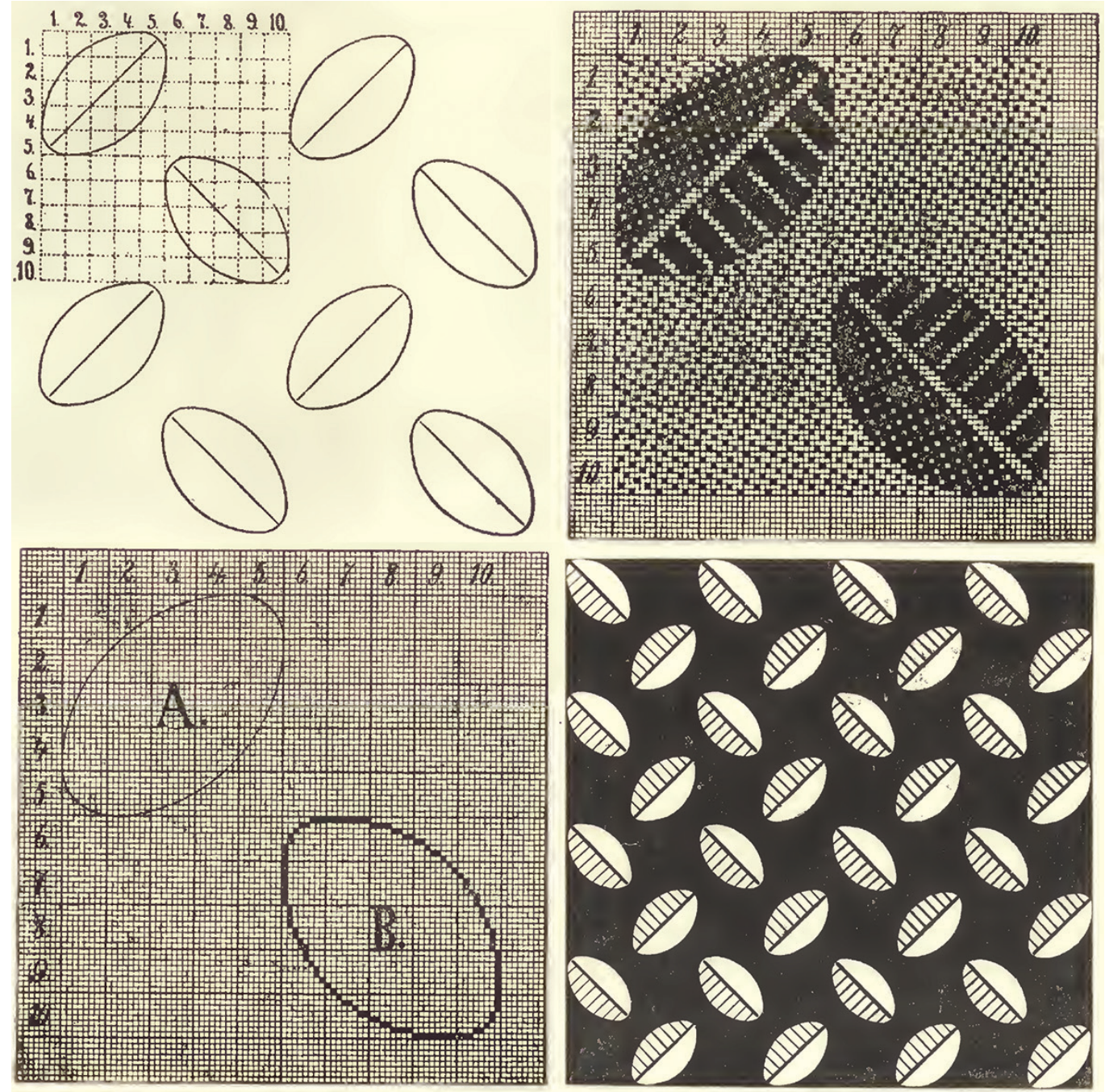

g. 9. Outlining in

and fabric sample (image

from: Posselt 1893, pp.

I I5, | | 6). 
Fig. 10. Aleksandra Gaca, An example of 3D woven textile (image from: aleksandragaca.eu).

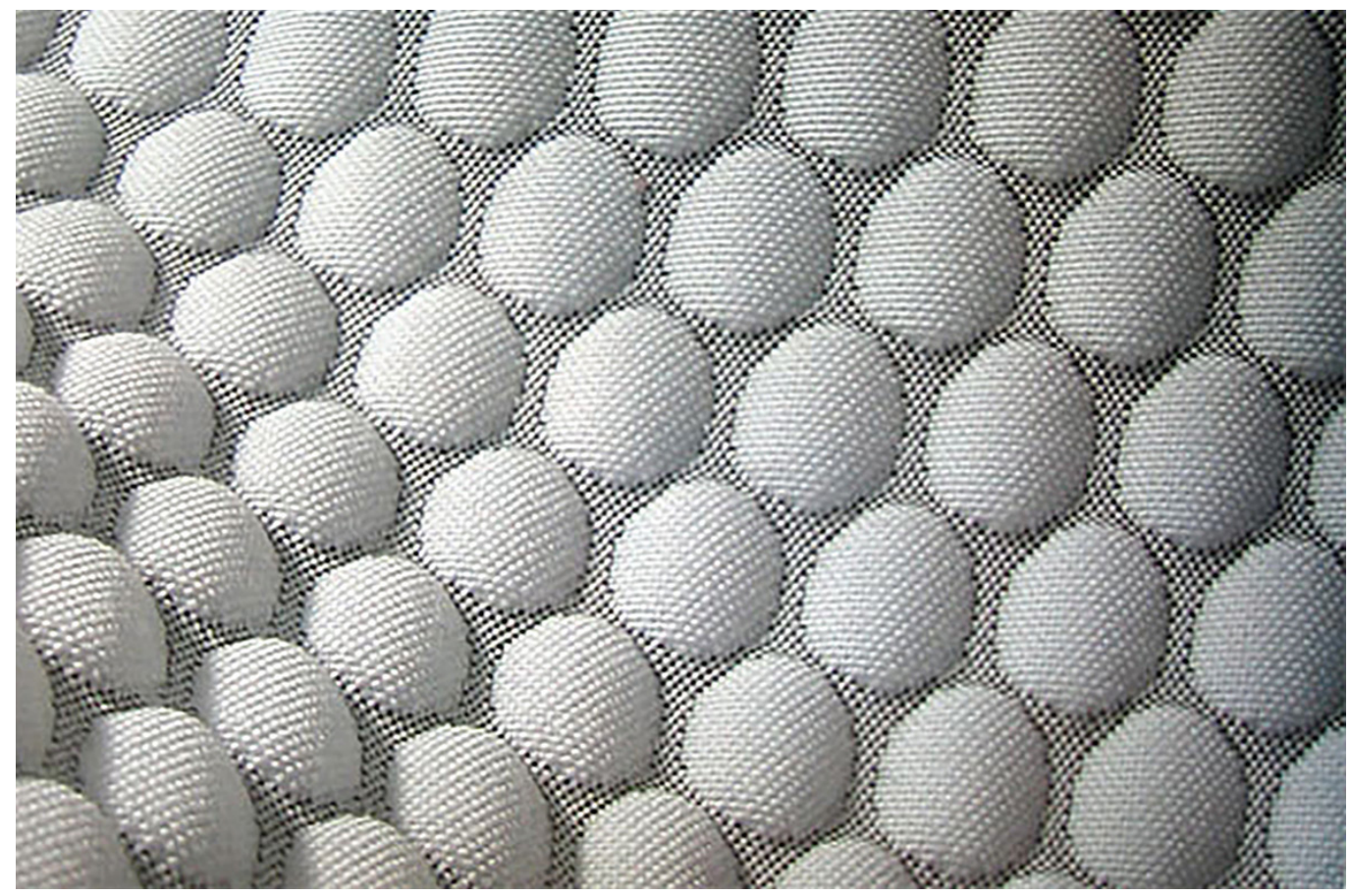

Fig. I I. Lim Kae Woei, Elena Low, 3D printed fabric obtained using parametric solid modelling rametric solid modelling software. Source: image from http://www.xyzworkshop.com/flv_portfo singapore-2/ (photo credit: Memento inc.).
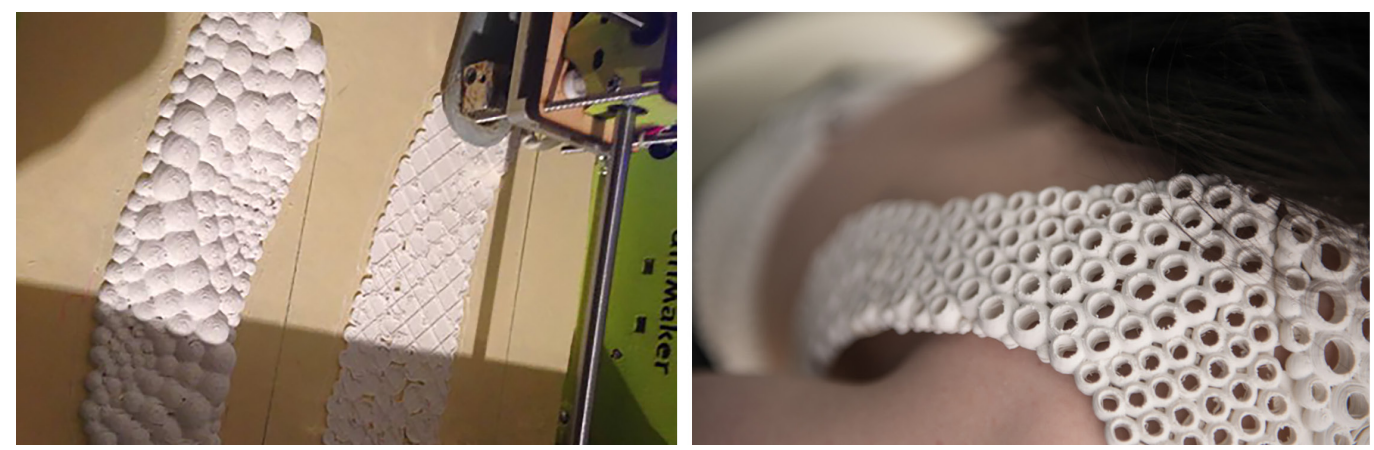

Notes

[I] Franz Sales Meyer (1849-1927) was professor at the Großherzoglichen Badischen Kunstschule (Grand Ducal Schoo of Applied Arts) in Karlsruhe. His Ornamental Formenlehre text of 1886, translated into English in 1896 under the title A Handbook of Ornament, follows a series of studies on ornamentation. Among these, the pioneering work of Owen Jones ( 1809 - | 874), architect, designer and theorist of the Victorian era, whose writing The Grammar of Ornament, published in I 856 represents the most complete chromatic print editorial work on the history of the decoration [Jones 1856].

[2] Meyer identifies three groups of geometric ornaments: continuous and ribbon like (bands), enclosed spaces (panels) and unlimited flat patterns [Meyer 1920, p. 3]

[3] About the flat patterns Hann writes: "The principal characteristic of a regular repeating pattern is the repetition (or translation) of a motif by a given distance across the plane. Where repetition is continuous in one direction only, between two lines (either real or imaginary), the pattern thus produced may be referred to as a 'border pattern'; synonymous terms include 'strip pattern','frieze group' or 'one-dimensional design'. Where repetition is continuous in two independent directions, covering the plane, the resultant pattern may be referred as an 'all-over pattern': synonymous terms include 'wallpaper pattern', 'periodic pattern', or 'crystallographic pattern' [Hann 2003, p. 55]

[4] These lattice, also take the name of Bravais lattice inheriting the name from the French physicist Auguste Bravais ( $|8|$ I1863) who first classified them in his exhaustive study on crystals of 1848. He identified 5 of them in the plane and 14 in space [See Bravais 1949].

[5] Motifs are also defined as 'finite figures', 'bounded figures' or 'point groups' [Hann 2003, p. 55]. 
[6] Depending on the constituent symmetry characteristics, motifs may be classified using the notation cn (c for cyclic) or dn ( $\mathrm{d}$ for dihedral). The cyclic ones have $\mathrm{n}$-fold rotational symmetry; the dihedral ones have $\mathrm{n}$ distinct reflexion axes as well as n-fold rotational symmetry [Thomas, Hann 2007, p. 10]

[7]The possibilities of obtaining a huge variety of designs are historically linked to the invention, in 1804 , of the so-called lacquard machine, named after its inventor Joseph Marie Jacquard (1752-1854), which represents perhaps the most revolutionary innovation in textile art (Hobsbawn 1996, p. 30). The Jacquard machine offered the possibility to speed up the weaving work, to weave with a single movement, hundreds of threads with a single evolution (today more than 10000), allowing the realization of complex geometric drawings and to increase the dimensions of the fabric. The sequence of operations was controlled by a series of replaceable punched cards to be inserted in the head of the loom. See Posselt I893. Precisely for this reason the Jacquard machine has been considered an innovation closely linked to the history of computing hardware [Essinger 2004].

\section{References}

Bravais Auguste (1949). On the systems formed by points regularly distributed on a plane or in space. Crystallographic Society of America, Mem. I, translated by Amos J. (Ed. originale Bravaiș Auguste (1850). Sur les systèmes formés pardes points distribués régulièrement sur un plan au dans l'espace. In Journal de l'École Polytecnique, Cahier 33, tome 19, I 850, pp. I- 128).

Chen Xiaogang (ed.). (2015). Advances in 3D Textiles. Cambridge:Woodhead Publishing Limited.

Christie Archibald H. (1910). Traditional methods of Pattern Designing. Oxford: Claredon Press.

Davis Philip J., Hersh Reuben (1986). Descartes' Dream. Brighton: Harvester Press.

Day Lewis F. (1903). Pattern Design. London: B.T. Batsford Ltd.

De Paolis Roberto (2012). II disegno della superficie: dal tessuto d'arredo al rivestimento di interni. In Rossi Michela (a cura di). Il Disegno come Ricerca. Strumenti grafici e modelli rappresentativi per il progetto. Santarcangelo di Romagna: Maggioli.

Essinger James (2004). How a hand-loom led to the birth of the information age. Oxford: Oxford University Press.

Grünbaum Branko, Shephard Geoffrey C. (1987). Tilings and Patterns. New York: Freeman.

Hann Michael A. (2003). The Fundamentals of Pattern Structure. Part I: Woods Revisited. In The Journal of The Textile Institute, $94,1-2$, pp. 53-65.

Hobsbawn Eric J. (1996). The Age of Revolution, 1789-1898. New York:Vintage Books Editions.

Horne Clare E. (2000). Geometric symmetry in patterns and tilings. Cambridge:Woodhead Publishing Ltd.

Jones Owen (1856). The Grammar of Ornament. London: Day and Son.

Kappraff Jay (1990). Connections: The Geometric Bridge Between Art and Science. New York: McGraw-Hill.

Kubovy Michael (1994). The perceptual organization of dot lattices. In Psychonomic Bullettin \& Review, I, pp. $182-190$.

Meyer Franz S. (1920). A Handbook of Ornament. First american Edition. New York:Architectural Book Publishing Company. (Ed. orig. Ornamentale Formenlehre. Leipzig: E.A. Seemann, I886, in folio).

Posselt Emanuel A. ( 1893$)$. The Jaquarde Machine. Philadelphia: Posselt.

Stephenson Charles, Suddards Frank ( 1897). A Textbook Dealing with Ornamental Design for Woven Fabrics. London: Methuen.

Thomas Briony G., Hann Michael A. (2007). Patterns in the Plane and Beyond: Symmetry in Two and Three Dimensions. Leeds: University of Leeds International Textiles Archive.

Thompson D'Arcy W. (2016). Crescita e forma: la geometria della natura. Edizione ridotta a cura di John Tyler Bonner. Milano: Bollati Boringhieri. (Ed. orig. On Growth and Form. An Abriged Edition edited by J.T. Bonner, Cambridge: Cambridge University Press, 1961).

Washburn Doroty K., Crowe Donald W. (1991). Symmetries of Culture: Theory and Practice of Plane Pattern Analysis. Seattle: University of Washington Press.

Watson William (1921). Textile Design and Colour, Elementary Weaves and Figured Fabrics (second edition). London: Longmans, Green and co.

\section{Author}

Stefano Chiarenza, Università San Raffaele Roma, stefano.chiarenza@uniroma5.it

To cite this chapter. Chiarenza Stefano (2020). Arte e geometria nel disegno tessile/Art and geometry in textile drawing. In Arena A., Arena M., Brandolino R.G., Colistra D., Ginex G., Mediati D., Nucifora S., Raffa P. (a cura di). Connettere. Un disegno per annodare e tessere. Atti del $42^{\circ}$ Convegno Internazionale dei Docenti delle Discipline della Rappresentazione/Connecting. Drawing for weaving relationships. Proceedings of the 42th International Conference of Representation Disciplines Teachers. Milano: FrancoAngeli, pp. 296-315. 